\title{
Chronology and impact of the 2011 Cordón Caulle eruption, Chile
}

\author{
Manuela Elissondo ${ }^{1}$, Valérie Baumann ${ }^{1}$, Costanza Bonadonna ${ }^{2}$, Marco Pistolesi ${ }^{3}$, Raffaello Cioni ${ }^{3}$, \\ Antonella Bertagnini ${ }^{4}$, Sébastien Biass ${ }^{2}$, Juan-Carlos Herrero ${ }^{1}$, and Rafael Gonzalez ${ }^{1}$ \\ ${ }^{1}$ Servicio Geológico Minero Argentino (SEGEMAR), Buenos Aires, Argentina \\ ${ }^{2}$ Department of Earth Sciences, University of Geneva, Geneva, Switzerland \\ ${ }^{3}$ Dipartimento di Scienze della Terra, Università di Firenze, Firenze, Italia \\ ${ }^{4}$ Istituto Nazionale di Geofisica e Vulcanologia, Pisa, Italia
}

Correspondence to: Costanza Bonadonna (costanza.bonadonna@unige.ch)

Received: 7 July 2015 - Published in Nat. Hazards Earth Syst. Sci. Discuss.: 8 September 2015

Accepted: 29 January 2016 - Published: 10 March 2016

\begin{abstract}
We present a detailed chronological reconstruction of the 2011 eruption of the Cordón Caulle volcano (Chile) based on information derived from newspapers, scientific reports and satellite images. Chronology of associated volcanic processes and their local and regional effects (i.e. precursory activity, tephra fallout, lahars, pyroclastic density currents, lava flows) are also presented. The eruption had a severe impact on the ecosystem and on various economic sectors, including aviation, tourism, agriculture and fishing industry. Urban areas and critical infrastructures, such as airports, hospitals and roads, were also impacted. The concentration of $\mathrm{PM}_{10}$ (particulate matter $\leq 10 \mu \mathrm{m}$ ) was measured during and after the eruption, showing that maximum safety threshold levels of daily and annual exposures were surpassed in several occasions. Probabilistic analyses suggest that this combination of atmospheric and eruptive conditions has a probability of occurrence of about $1 \%$. The management of the crisis, including evacuation of people, is discussed, as well as the comparison with the impact associated with other recent eruptions located in similar areas and having similar characteristics (i.e. Quizapu, Hudson and Chaitén volcanoes). This comparison shows that the regions downwind and very close to the erupting volcanoes suffered very similar problems, without a clear relation to the intensity of the eruption (e.g. health problems, damage to vegetation, death of animals, roof collapse, air traffic disruptions, road closure, lahars and flooding). This suggests that a detailed collection of impact data can be largely beneficial for the development of plans for the management of an eruptive crisis and the mitigation of associated risk of the Andean region.
\end{abstract}

\section{Introduction}

Recent volcanic crises (e.g. Chaitén 2008, Cordón Caulle 2011 and Calbuco 2015, Chile; Eyjafjallajökull 2010, Iceland) clearly demonstrated that even small-moderate to subplinian eruptions, particularly if long-lasting, can paralyze entire sectors of societies with a significant economic impact. The increasing complexity of the impact of eruptions on modern societies, related to the interaction between natural, technological and social aspects, requires a shift in thinking in the field of risk analysis and management. As an example, the following was discussed in the Munich Re (2011) report: (i) integrated prevention on all levels is essential in view of the immense loss potential; (ii) specific research is needed to fill the gaps in our knowledge and analyse cause-and-effect chains; (iii) loss prevention programmes must be implemented on a local, regional, national and international level, in both the private and the public sector. Actions necessary for preparedness require consideration of hazard, vulnerability and corresponding risk for the development of comprehensive and reliable contingency plans. In this paper we study the local impact of the 2011 eruption of Cordón Caulle volcano (Chile) that dispersed a large volume of rhyolitic tephra over Chile and Argentina during 9 months, reaching as far as the Atlantic and the Pacific oceans (e.g. Collini et al., 2012; Pistolesi et al., 2015; Bonadonna et al., 2015a, b; Wilson et al., 2013). In particular, we report and discuss the effects of this well-studied eruption on the population, infrastructures and the environment to better constrain the relationship between natural phenomena and society response, which is a necessary first step to improve preparedness. 
The Puyehue-Cordón Caulle volcanic complex (PCCVC) is located in the southern volcanic zone of the central Andes. This Pleistocene-Holocene complex comprises a $20 \mathrm{~km}$ long, NW-SE-oriented fissure system (Cordón Caulle; CC) and a stratovolcano topped by a summit caldera (Puyehue) to the SE, together with some remnants of other Pleistocene volcanoes (Lara et al., 2006; Singer et al., 2008). At least five historical eruptions have been recorded for the CC volcano (1759, 1893, 1921, 1960 and 1990). The impact of the 2011 eruption was limited to areas close to the volcano in Chile, while in Argentina a wide area was affected by tephra dispersal and fallout, including important towns such as Bariloche, Villa La Angostura and Ingeniero Jacobacci, between 50 and $240 \mathrm{~km}$ from CC (Fig. 1).

Post-event impact assessments are necessary to constrain the fragility of systems exposed to volcanic hazards in order to better forecast the consequences of future eruptions (e.g. Blong, 1984, 2003; Hampton et al., 2015; Jenkins et al., 2014; Johnston et al., 2000; Magill et al., 2013; Martin et al., 2009; Milazzo et al., 2013; Stewart et al., 2006; Wardman et al., 2012; Wilson et al., 2010, 2011a, 2012, 2013). In this study, we compile data from various sources to reconstruct a precise chronology of the local and regional impacts that followed the 2011 CC eruption. Reports on the management of the crisis at different localities in Argentina are also given, where ash dispersal and deposition strongly impacted environment, population and various economic sectors. In the final part of this paper we also compare the impact of other moderate to large explosive eruptions in the Andes of the last century, and we present a probabilistic analysis of atmospheric and eruption conditions in order to evaluate the possible impact of future eruptions.

\section{Note on non-academic sources and terminology}

The large variety of sources used in this study was considered with various degrees of confidence, amongst which technical reports were judged the most reliable (see Appendix A for the non-academic sources). Newspaper articles were used mostly to constrain the chronology of events (e.g. date and duration of tephra fallouts in various localities) and assess the impact on the aviation sector (e.g. dates, duration and location of ground traffic interruption, services interruption, flight cancellations and airports closure). It must be noted that the data published in the newspapers about the characteristic of the tephra deposit were not considered reliable as large discrepancies were observed between deposit thickness measured in the field vs. those reported in the media (see Sect. 7.1). When possible, newspaper articles were corroborated with MODIS and/or GOES satellite images.

Considering that some of the information is taken from newspapers and technical reports, with the term "ash" we refer here to the general connotation of "tephra", i.e. pyroclastic particles irrespective to size, morphology and composition injected into the atmosphere during volcanic explosions.

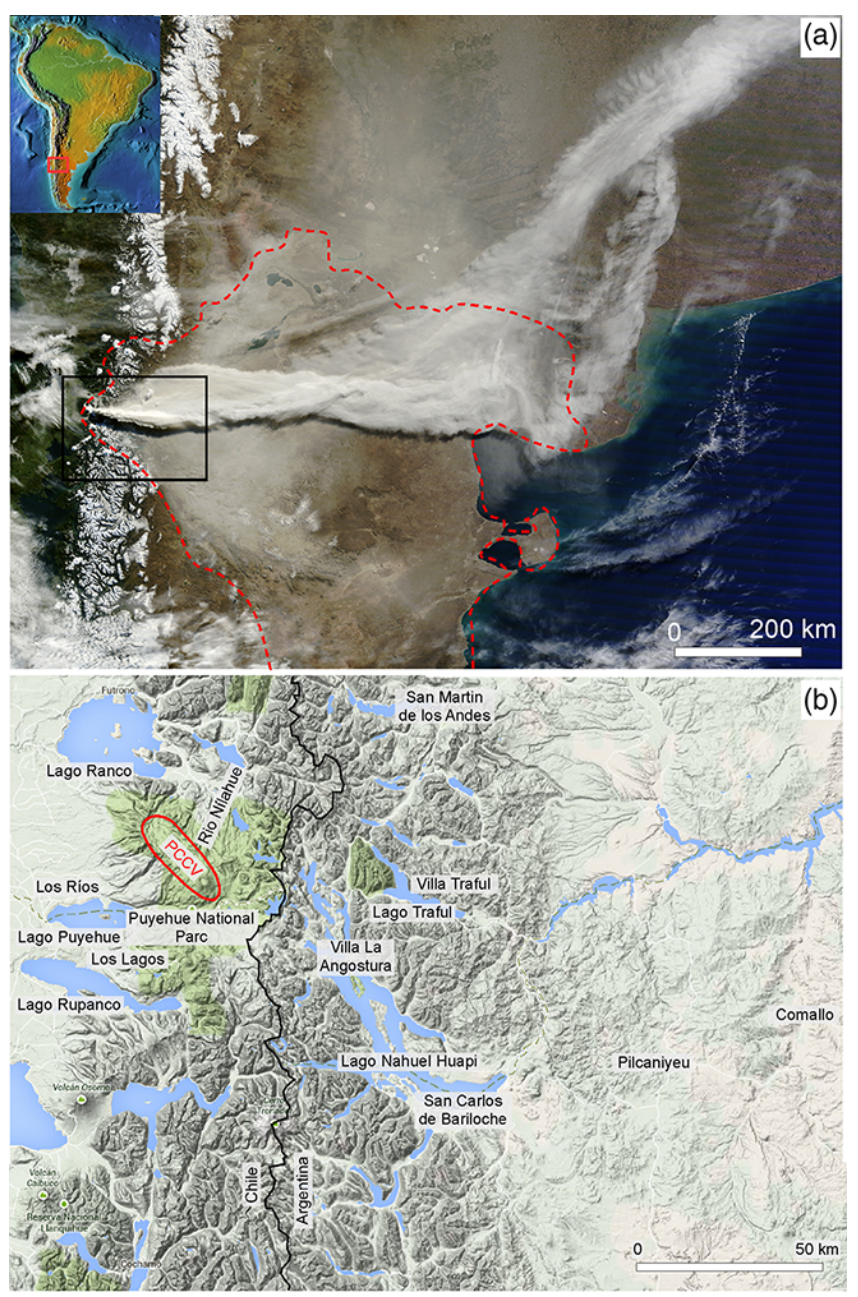

Figure 1. (a) Nasa image from Moderate Resolution Imaging Spectroradiometer (MODIS) on the Terra satellite, showing ash on the ground and a large plume streaming east from Puyehue volcano on 13 June 2011. The red dashed line indicates the extension of the tephra deposit (Gaitán et al., 2011). The black square represents the area shown in (b). (b) Google image of the proximal area affected by tephra fallout, between Chile and Argentina (border is the black line).

In addition, we use the term "lahar" to indicate a mixture of rock debris and water, which encompasses a continuum from debris flow (sediment concentration $\geq 60 \%$ per volume) to hyperconcentrated streamflows (sediment concentration from 20 to $60 \%$ per volume) (Lavigne and Thouret, 2000). Finally, with re-suspension we describe aeolian remobilization of pyroclastic deposits (e.g. Wilson et al., 2011b; Folch et al., 2014).

\section{Ecosystem and local economic activities}

In the area impacted by the eruption, three natural regions are present from west to east: southern Andes, Andean foothills 


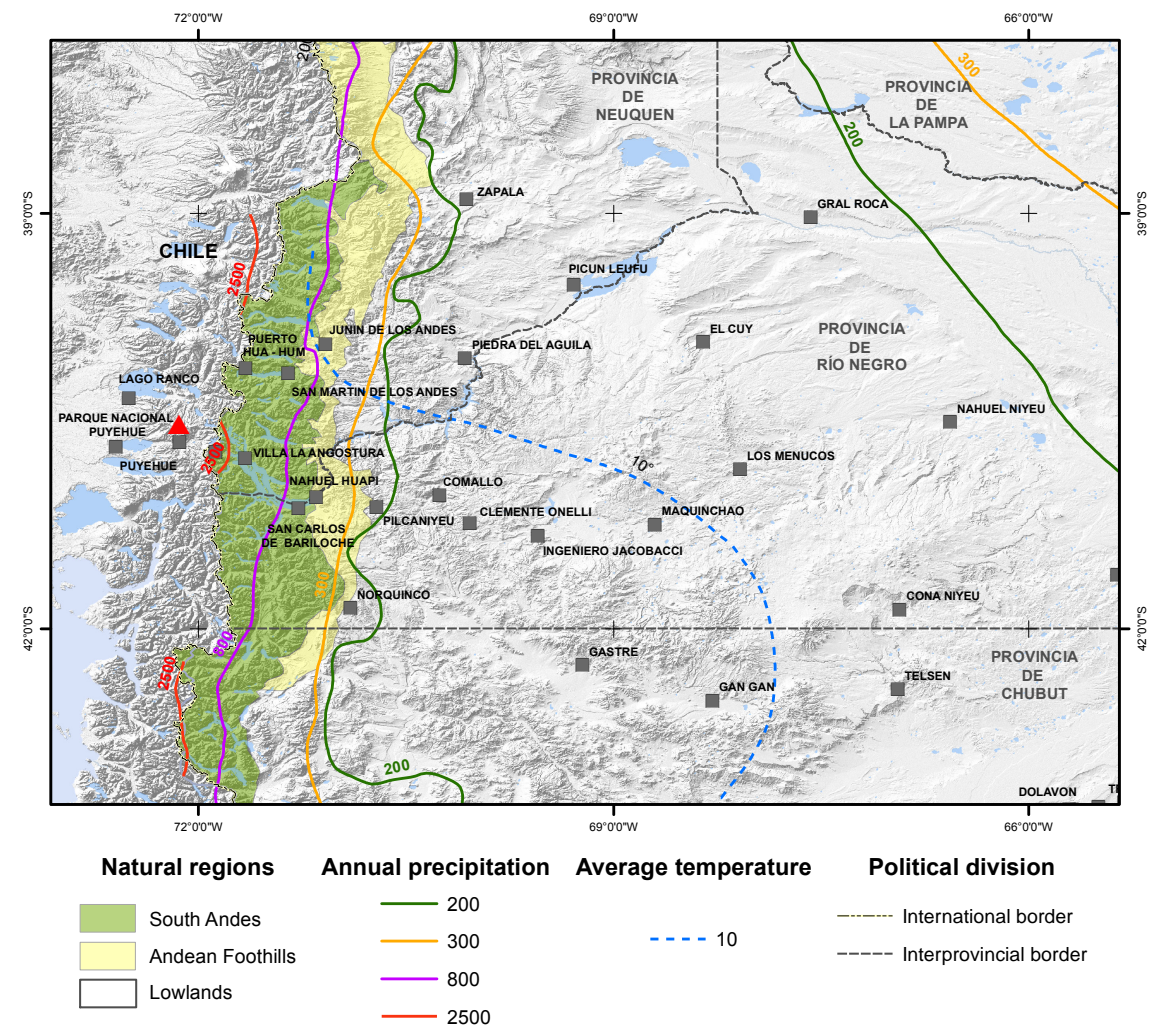

Figure 2. Natural regions of the northern portion of Argentine Patagonia, modified from Bran et al. (2000, 2002). The solid lines represent the average annual precipitation and the dashed line represents the average annual temperature (taken from INTA, Instituto Nacional de Teconología Agropecuaria and SMN, Servicio Meteorológico Nacional).

and lowlands (Fig. 2) (Bran et al., 2000, 2002).The southern Andes present an average elevation at c. $2000 \mathrm{~m}$, with the highest peak at Lanín volcano (3776 m above sea level; a.s.l.). The landscape is characterized by glacially sculpted steep slopes, glacial and tectonic lakes and flat valley floors of fluvial and glacio-fluvial outwash. The climate is cold, with an average temperature of $10^{\circ} \mathrm{C}$ and an annual precipitation varying between 800 and $2500 \mathrm{~mm}$, with most of the precipitation occurring in winter (June-August) mainly as snowfall. The vegetation between $\mathrm{CC}$ volcano and Villa $\mathrm{La}$ Angostura is the Valdivian rain forest. Tourism is the most important activity in this area.

Andean foothills are located east from the southern Andes; annual precipitation varies between 800 and $300 \mathrm{~mm}$ from west to east. The vegetation includes a steppe of grasses, shrubs and wet meadows covering $5-10 \%$ of the area. The main activity is the pastoral farming of cows and sheep. Lowlands (also called extra-Andean Patagonia) are located in the eastern sector; the climate is dry and cold with annual precipitation varying between 200 and $300 \mathrm{~mm}$ (Fig. 2). The area is characterized by a steppe of grasses and shrubs with wet meadows covering $3 \%$ of the area. The main activity is the extensive pastoral farming of cows, sheep and goats.

\section{Eruption chronology}

The chronology described in this chapter includes both information on the pre-eruptive period as well as data collected during the eruption, i.e. National Service of Geology and Mining of Chile Volcano Observatory of the southern Andes (SERNAGEOMIN-OVDAS, 2010-2012), Buenos Aires Volcanic Ash Advisory Center (VAAC Buenos Aires) and satellite imagery (MODIS-Aqua Terra, GOES).

\subsection{Pre-eruptive period}

SERNAGEOMIN-OVDAS has been monitoring the PCCVC since 2010. During the period between June 2010 and March 2011, all the monitoring reports on volcanic activity fixed an alert Level 1 (Table 1). The seismic record for that period mainly included volcano-tectonic (VT) earthquakes with magnitudes lower than 2.7 and depths of about $10 \mathrm{~km}$ (Table 1). From August 2010 seismic activity in the area of the Cordillera Nevada-Cordón Caulle increased, with long period (LP) earthquakes registered in September 2010 related to hydrothermal processes or release of magmatic gases at low pressure. From March 2011 OVDAS reported a significant further increase in seismicity peaking on 19 April, when the alert level was raised to Level 2 - green (Table 1). On 
Table 1. Pre-eruptive activity of the PCCVC from June 2010 to June 2011. The table includes alert level and type, number and location of earthquakes. Magnitude corresponds to ML: local magnitude, except indication in brackets which corresponds to MD: duration magnitude; $\mathrm{eq}^{-1}$ : earthquakes per hour; VT: volcano tectonic; LP: long period; HB: hybrid; LOFZ: Liquiñe-Ofqui fault zone, CC: Cordón Caulle. Taken from SERNAGEOMIN-OVDAS, 2010-2012.

\begin{tabular}{|c|c|c|c|c|c|c|}
\hline Month & Alert level & Period & \# of events & Type & Magnitude (ML) & Location and depth (km) \\
\hline June 2010 & 1-green & & 41 & VT & $<2.3(\mathrm{MD})$ & related to $\mathrm{LOFZ}$ \\
\hline July 2010 & 1-green & & 12 & VT & $<1.8(\mathrm{MD})$ & related to $\mathrm{LOFZ}$ \\
\hline \multirow{2}{*}{ August 2010} & \multirow{2}{*}{ 1-green } & & 125 & \multirow{2}{*}{ VT } & & related to $\mathrm{LOFZ}$ \\
\hline & & 10 to $15-08-11$ & 68 & & $<2(\mathrm{MD})$ & C. Nevada-Puyehue, $<10$ \\
\hline \multirow{2}{*}{ September 2010} & \multirow{2}{*}{ 1-green } & & 46 & VT & $<2(\mathrm{MD})$ & $10-11$ \\
\hline & & & 4 & LP & & \\
\hline \multirow{2}{*}{ October 2010} & \multirow{2}{*}{ 1-green } & & 67 & VT & $<2(\mathrm{MD})$ & C. Nevada, $\leq 11$ \\
\hline & & & 2 & LP & & \\
\hline \multirow{2}{*}{ November 2010} & \multirow{2}{*}{ 1-green } & & 121 & VT & $<2(\mathrm{MD})$ & Cordón Caulle, $\leq 10-11$ \\
\hline & & & 1 & LP & & \\
\hline December 2010 & 1-green & & 39 & VT & $<2(\mathrm{MD})$ & C. Nevada-Puyehue, $\leq 10-11$ \\
\hline January 2011 & 1-green & & 49 & VT & $<2.1(\mathrm{MD})$ & C. Nevada-Puyehue, $\leq 10$ \\
\hline \multirow{2}{*}{ February 2011} & \multirow{2}{*}{ 1-green } & & 85 & VT & $<2.1$ (MD) & \multirow{2}{*}{ C. Nevada-Puyehue-LOFZ, $\leq 10$} \\
\hline & & & 2 & LP & & \\
\hline March 2011 & 1-green & & 70 & VT & $<2.7(\mathrm{MD})$ & C C.-C. Nevada, $\leq 9$ \\
\hline \multirow{9}{*}{ April 2011} & \multirow{3}{*}{ 2-green } & \multirow{2}{*}{$19-04-11$} & 1 & VT & 3.4 & C. Nevada-C C., 5 \\
\hline & & & 187 & Swarm & & C. Nevada-C C., 4-6 \\
\hline & & \multicolumn{5}{|l|}{ 26-04-11 } \\
\hline & \multirow{6}{*}{ 3-yellow } & \multirow[t]{2}{*}{ 27-04-11 } & 185 & Swarm HB & $<3$ & PCCVC, 4-6 \\
\hline & & & 1 & $\mathrm{HB}$ & 3.9 & PCCVC, 4 \\
\hline & & \multirow{2}{*}{ 29-04-11 } & 56 & Swarm VT & $<2.4$ & C. Nevada-C C., 4-6 \\
\hline & & & 1 & VT & 3.1 & C. Nevada-C C., 4,8 \\
\hline & & \multirow{2}{*}{01 to $30-04-11$} & 1050 & VT & & \\
\hline & & & 214 & $\mathrm{HB}$ & & \\
\hline \multirow{12}{*}{ May 2011} & \multirow{12}{*}{ 3-yellow } & $04-05-11$ & & \multirow{5}{*}{$\mathrm{HB}$} & 3.6 & CC. 3.5 \\
\hline & & 08-05-11 & & & 3.1 & SW C. Nevada Caldera, 3.4 \\
\hline & & $09-05-11$ & & & 3.3 & 4.8 \\
\hline & & \multirow{2}{*}{$17-05-11$} & & & 4.2 & $\mathrm{CC}, 8$ \\
\hline & & & 20 eq in $2 \mathrm{~h}$ & & $<3$ & \\
\hline & & \multirow{3}{*}{01 to $17-05-11$} & 364 & VT & & \\
\hline & & & 207 & $\mathrm{HB}$ & & \\
\hline & & & 6 & LP & & \\
\hline & & $30-05-11$ & 37 & Swarm HB & & \\
\hline & & & 1 & $\mathrm{HB}$ & 3.4 & C. Nevada, 2.3 \\
\hline & & $31-05-11$ & 1 & $\mathrm{HB}$ & 3.3 & $\mathrm{C} \mathrm{C}, 3$ \\
\hline & & & 25 & Swarm HB & & \\
\hline & 3-yellow & 02-06-11 & $750\left(20 \mathrm{eqh}^{-1}\right)$ & Swarm HB LP & & SE C C, 2-5 \\
\hline June 2011 & & & 1 & $\mathrm{HB}$ & 3.8 & 3.7 \\
\hline Jenc 2011 & 4-yellow & 03-06-11 & $140\left(25 \mathrm{eqh}^{-1}\right)$ & HB LP & 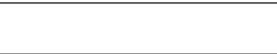 & $\mathrm{SE} \mathrm{CC}, 2-5$ \\
\hline & & & $1450\left(60 \mathrm{eqh}^{-1}\right)$ & HB LP & 130 eq $>2$ & $\mathrm{SE} \mathrm{CC}, 2-5$ \\
\hline & 5-red & 04-06-11 & $230 \mathrm{eqh}^{-1}$ & Swarm HB LP & $12>4 / 50>3, \operatorname{Max} 4.4$ & $\mathrm{C} \mathrm{C}, 1-4$ \\
\hline
\end{tabular}


26 April, residents reported the presence of a gas and ash column rising from the area of International Chile-Argentina border (Cardenal Samoré pass). SERNAGEOMIN staff installed two additional seismographs and conducted an overflight that did not reveal any substantial change in the volcanic activity. On 27 April 2011 a seismic swarm below the $\mathrm{CC}$ system was recorded and the alert level was changed to Level 3 - yellow (Table 1). During the month of May, seismic activity below the PCCVC increased, and both hybrid (HB) and LP earthquakes were recorded; on 4 and 17 May two events were recorded with local magnitudes of 3.6 and 4.2 , respectively, which were clearly perceived by the population. SERNAGEOMIN warned about the possible destabilization of the volcanic system and the alert level remained at Level 3. On 1 June, a significant change in seismic activity was reported, with a seismic swarm characterized by LPand HB-type events (c. 750 events in $32 \mathrm{~h}$ ) located SE of CC and showing a migration of hypocentres toward shallower levels $(2-5 \mathrm{~km})$. On 2 June, an average of 25 earthquakes per hour was recorded, including a 3.8 magnitude, HB-type event. Due to this new escalation in seismic activity, the alert was raised to Level 4 - orange (SERNAGEOMIN-OVDAS, 2010-2012). On 3 June seismic activity increased to an average of 60 earthquakes per hour (LP and HB types). During the morning of 4 June, seismicity evolved to 230 earthquakes per hour, 12 of them with local magnitude greater than 4 and 50 with magnitudes greater than 3 ; seismic activity was also characterized by high-energy tremor located in the vicinity of the CC complex, between 1 and $4 \mathrm{~km}$ of depth. Alert level was changed to Level 5 - red (Table 1), implying imminent eruption (SERNAGEOMIN-OVDAS, 2010-2012).

\subsection{Eruptive dynamics and volcanic cloud evolution}

On 4 June, around 14:45 local time (LT) (i.e. 18:45 UTC), the eruption began with the generation of a $10-14 \mathrm{~km}$ a.s.l. high and $5 \mathrm{~km}$ wide plume. Alert level was raised to Level 6 (moderate eruption, Table 2) (SERNAGEOMIN-OVDAS, 20102012). According to the local media, around 19:00 UTC, the ash cloud reached the Chile-Argentina international border, where "a rain of hail made of volcanic material" was reported. In Villa La Angostura (48 km from the vent), a fallout of "small stones" was reported in the afternoon, which evolved to fallout of finer material around midnight. In Bariloche ( $98 \mathrm{~km}$ SE of the vent) the sky became dark and ash began to fall at 19:10 UTC, accompanied by clearly audible explosions.

On 5 June, the plume reached the Atlantic Ocean $1800 \mathrm{~km}$ ESE of the volcano, while a large area of Argentina territory was already affected by ash fall. In the morning, the intensity of tephra fallout increased in Villa La Angostura, where the deposit of ash and fine lapilli reached a thickness of about $20 \mathrm{~cm}$. In the town of Villa Traful $(65 \mathrm{~km}$ east from the vent) ash began to fall at 22:00 UTC on 5 June, where the media reported intense ash fall and an accumulation of $2 \mathrm{~cm}$ of ash. On the same day, at 21:45 UTC OVDAS reported the generation of at least 5 pyroclastic density currents (PDCs) that moved north of the vent along the river Nilahue valley (Fig. 1).

The southern part of Río Negro province was affected by ash fall since 5 June. Ash fall was reported at Pilcaniyeu, Comallo, Ingeniero Jacobacci, Maquinchao and Los Menucos, referred to as "Línea Sur" (136, 168, 237, 300 and 344 km from the vent, respectively; Fig. 3). In Jacobacci, the media reported that ash reached a thickness of $4-10 \mathrm{~cm}$ and had a "talc-like" aspect. In the Chubut (Fig. 2) region, the area covered by ash was estimated at $200 \mathrm{~km}^{2}$. In Chile, ash fall was reported in the town of Entre Lagos and in Termas de Puyehue, and also affected the nearby rural areas of Lago Ranco.

On 6 June, the plume abruptly changed direction toward NNE and then shifted direction again towards SE, at about $1000 \mathrm{~km}$ from the vent, reaching the Atlantic Ocean about $3000 \mathrm{~km}$ downwind. Ash fall was recorded in the towns of San Martín de los Andes (from 05:00 to 08:00 UTC), where tephra accumulation was in the order of few millimetres up to $10 \mathrm{~cm}$ in some areas. In Bariloche and Villa La Angostura, ash fallout was recorded since the morning and with greater intensity in the afternoon, although according to the press, the episode was less intense than that which occurred on 4 June. The tephra dispersal area reached the southern part of the province of Buenos Aires and the provinces of San Luis, Mendoza, San Juan, La Pampa and Córdoba, between 800 and $1400 \mathrm{~km}$ from CC.

On 7 June, the plume reached 5.5-9.8 km a.s.l. with ESE orientation (Buenos Aires VAAC). According to the media, on that day ash fallout remained intense especially in southern Neuquén region. In Villa La Angostura, ash fall mixed with rain was reported during the night.

On 8 June, the volcanic cloud ( $10 \mathrm{~km}$ high a.s.1.) was dispersed towards NE with a bend toward SE $400 \mathrm{~km}$ away from the vent. OVDAS also reported PDCs in the $\mathrm{Ni}$ lahue valley, where the river reached a temperature of $45^{\circ} \mathrm{C}$ (SERNAGEOMIN-OVDAS, 2010-2012). The west portion of Neuquén and Río Negro provinces was severely affected by ash fall, with strong winds remobilizing most of the deposited tephra.

On 9 June, the plume had a NE direction. Ash reached Buenos Aires, Montevideo and southern Brazil, generating important flight cancellations. In Villa La Angostura and Villa Traful, rain reduced ash re-suspension.

On 10 June, the plume was dispersed to the ESE. Ash resuspension was reported in many areas of the "Línea Sur". Two lahars that affected main roads were generated, one close to the International border on the international road 231 and the second near Villa Traful on road 234. On 11 June, the eruption column showed oscillating height and reached a maximum height of $4.5-6 \mathrm{~km}$ a.s.l. in the morning. From 19:00 UTC ash fell again in Bariloche, although with finer grain-size compared to the beginning of the eruption. Around 
Table 2. Eruptive activity of the PCCVC during June 2011. The table includes alert level; type, number and location of earthquakes; seismic tremors; plume height and volcanic processes. ML: local magnitude, VT: volcano tectonic; LP: long period; HB: hybrid; LOFZ: LiquiñeOfqui fault zone, CC: Cordón Caulle; CT: continuous tremor; TP: tremor pulses; HT: harmonic tremor. Taken from SERNAGEOMINOVDAS, 2010-2012; Buenos Aires VAAC and satellite images.

\begin{tabular}{|c|c|c|c|c|c|c|c|c|c|c|}
\hline \multirow{2}{*}{$\begin{array}{l}\text { Alert } \\
\text { level }\end{array}$} & \multirow[t]{2}{*}{ Period } & \multirow{2}{*}{$\begin{array}{l}\text { Number } \\
\text { of } \\
\text { events }\end{array}$} & \multirow[t]{2}{*}{ Type } & \multirow{2}{*}{$\begin{array}{l}\text { Magnitude } \\
\text { (ML) }\end{array}$} & \multirow{2}{*}{$\begin{array}{l}\text { Location } \\
\text { and depth } \\
(\mathrm{km})\end{array}$} & \multirow{2}{*}{$\begin{array}{l}\text { Seismic } \\
\text { tremor } \\
\left(\mathrm{cm}^{2}\right)\end{array}$} & \multicolumn{3}{|c|}{ Features of eruptive plume } & \multirow{2}{*}{$\begin{array}{l}\text { Volcanic } \\
\text { processes }\end{array}$} \\
\hline & & & & & & & $\begin{array}{l}\text { Height-OVDAS } \\
\text { (km a.v.) }\end{array}$ & $\begin{array}{l}\text { Height-BsAs VAAC } \\
\text { (km a.s.1.) }\end{array}$ & Orientation & \\
\hline \multirow{13}{*}{ 总 } & 04-06-11 & & Seisı & ic activity co & tinues. Eruption beg & & 10 & $10.7-13.7$ & SE & Tephra fallout \\
\hline & \multirow{2}{*}{$05-06-11$} & \multirow{2}{*}{$17 \mathrm{eqh}^{-1}$} & \multirow{2}{*}{ VT HB EX } & \multirow{2}{*}{$\max 3.2$} & \multirow{2}{*}{ SE CC., 4} & \multirow{2}{*}{ CT, 20} & \multirow{2}{*}{$10-12$} & \multirow{2}{*}{$10.7-12.2$} & \multirow{2}{*}{ SE } & Tephra fallout \\
\hline & & & & & & & & & & PDCs Nilahue river \\
\hline & 06-06-11 & $10 \mathrm{eqh}^{-1}$ & VT EX & $\max 3.2$ & SE CC., $2-5$ & $\mathrm{CT}, 20$ & 10 & - & NE-SE & Tephra fallout \\
\hline & 07-06-11 & $7 \mathrm{eqh}^{-1}$ & VT EX & $\max 2.8$ & SE CC., 2-4 & $\mathrm{CT}, 10$ & 7.5 & $5.5-9.8$ & E-SE & Tephra fallout \\
\hline & \multirow{2}{*}{ 08-06-11 } & $5 \mathrm{eqh}^{-1}$ & VT EX & $\max 2.6$ & SE CC., 4-6 & $\mathrm{CT}, 12$ & 7.5 & 10 & $\mathrm{NE}$ & Tephra fallout \\
\hline & & & & & & & & & & PDCs Nilahue river \\
\hline & 09-06-11 & $10 \mathrm{eqh}^{-1}$ & VT EX & $\max 2.9$ & SE CC., 3-11 & $\mathrm{CT}, 11$ & - & - & NE & Tephra fallout \\
\hline & $10-06-11$ & $5 \mathrm{eqh}^{-1}$ & VT EX & $\max 3.5$ & SE CC., 4-10 & $\mathrm{CT}, 10$ & 3.7 & 6 & SE & Tephra fallout \\
\hline & $11-06-11$ & $5 \mathrm{eqh}^{-1}$ & VT EX & $\max 2.3$ & SE CC., 3-5 & CT, 9-12 & 8 & $6-10$ & $\mathrm{E}$ & Tephra fallout \\
\hline & $12-06-11$ & $5 \mathrm{eqh}^{-1}$ & VT EX & $\max 2$ & - & $\mathrm{CT}, 9$ & - & 10 & $\mathrm{NE}$ & Tephra fallout \\
\hline & $13-06-11$ & $5 \mathrm{eqh}^{-1}$ & VT EX & $\max 2$ & $\mathrm{CC} .4$ & $\mathrm{TP}$ & 8 & 11 & $\mathrm{E}-\mathrm{NE}$ & Tephra fallout \\
\hline & & 4 & $\mathrm{HB}$ & 3 & & $2-20$ & & & & Balistics \\
\hline & $14-06-11$ & $10 \mathrm{eqh}^{-1}$ & HB VT EX & $\max 3.2$ & NW vent, 4 & $\mathrm{TP}$ & $8-9$ & $5.5-7.6$ & E-SE & Tephra fallout \\
\hline & & & & & & 2 to $12-15$ & & & & PDCs Nilahue river \\
\hline & $15-06-11$ & $4 \mathrm{egh}^{-1}$ & VT EX & $\max 2.5$ & W Puyehue & $\mathrm{CT}$ & $4-5 \mathrm{~km}$ & $4-8 \mathrm{~km}$ & E-SE & Tephra fallout \\
\hline & & & & & $2-4$ & 7 & & & & Lava flows \\
\hline & $16-06-11$ & $6 \mathrm{eqh}^{-1}$ & VT & $\max 3$ & Vent, 3 & HT, 60 & 3 & $4-8 \mathrm{~km}$ & E-SE & Tephra fallout \\
\hline 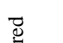 & & & & & & & & T-O КIII & L-SL & Lava flows \\
\hline & $17-06-11$ & $4 \mathrm{eqh}^{-1}$ & VT & $\max 2.3$ & $\begin{array}{l}\text { two sources: vent } \\
\text { and SW vent, }\end{array}$ & TP AND CT MAX 112 & 2 & $4-8 \mathrm{~km}$ & SE & Tephra fallout \\
\hline & & & & & $2-4 \mathrm{~km}$ & & & & & Lava flows \\
\hline & $19-06-11$ & $2 \mathrm{eqh}^{-1}$ & VT HB & $\max 2.1$ & CC., $2-5.5$ & TP AND CT, MAX 100 & $2 \mathrm{~km}$ & $4-8 \mathrm{~km}$ & SE & Tephra fallout \\
\hline & & & & & & & & & & Lava flows \\
\hline & $20-06-11$ & $2 \mathrm{eqh}^{-1}$ & VT HB & $\max 2.6$ & CC. , 2-6 & TP AND CT, MAX 124 & $5-6 \mathrm{~km}$ & $4-8 \mathrm{~km}$ & SE & Tephra fallout \\
\hline & & & & & & & & & & Lava flows \\
\hline & $21-06-11$ & $2 \mathrm{eqh}^{-1}$ & VT HB & $\max 2.5$ & CC. , $1-6.5$ & TP AND CT, MAX 100 & $3-4 \mathrm{~km}$ & $4-8 \mathrm{~km}$ & $\mathrm{NE}$ & Tephra fallout \\
\hline & & & & & & & & & & Lava flows \\
\hline & $22-06-11$ & $2 \mathrm{eqh}^{-1}$ & VT HB & $\max 2.6$ & CC. , 3.8- 4.5 & TP AND CT, MAX 74 & $3-4 \mathrm{~km}$ & $4-6 \mathrm{~km}$ & $\mathrm{NE}$ & Tephra fallout \\
\hline & & & & & & & & & & Lava flows \\
\hline & 23-06-11 & $3 \mathrm{eqh}^{-1}$ & VT HB & $\max 1.5$ & SSW CC., 1.4 & TP AND CT, MAX 47 & $? \mathrm{~km}$ & $4-6 \mathrm{~km}$ & $\mathrm{E}$ & Tephra fallout \\
\hline & & $30 \mathrm{~s} / 10 \mathrm{~min}$ & VT Swarm & $\max 2.2$ & & & & & & Lava flows \\
\hline & $24-06-11$ & $3 \mathrm{eqh}^{-1}$ & VT HB & $\max 2.9$ & CC., 2-9 & TP ANDCT, MAX 28 & $2-3 \mathrm{~km}$ & $4-6 \mathrm{~km}$ & NE & Tephra fallout \\
\hline & & & & & & & & & & Lava flows \\
\hline 产 & $25-06-11$ & $5 \mathrm{eqh}^{-1}$ & VT HB & $\max 2.8$ & CC., $0.5-5$ & TP AND CT, MAX 45.2 & $3-4 \mathrm{~km}$ & $4-6 \mathrm{~km}$ & $\mathrm{~N}$ & Tephra fallout \\
\hline 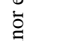 & & & & & & & & & & Lava flows \\
\hline 苞 & $26-06-11$ & $2 \mathrm{eqh}^{-1}$ & VT HB & $\max 2.1$ & CC., $0.5-5.5$ & TP AND CT, MAX 70 & $2-3 \mathrm{~km}$ & $4-6 \mathrm{~km}$ & N-NW & Tephra fallout \\
\hline & & & & & & & & & & Lava flows \\
\hline & $27-06-11$ & $3 \mathrm{eqh}^{-1}$ & VT HB & $\max 2.5$ & CC., 3-12 & TP AND CT, MAX 67 & $?$ & $4-6 \mathrm{~km}$ & $\mathrm{NE}$ & Tephra fallout \\
\hline & & & & & & & & & & Lava flows \\
\hline & 28-06-11 & $3 \mathrm{eqh}^{-1}$ & VT HB LP & $\max 1.9$ & CC., $1-5$ & CT, MAX 4 & $?$ & $4-6 \mathrm{~km}$ & E-NE & Tephra fallout \\
\hline & & 1 & VT & $\max 3.4$ & SW CC., 4.3 & & & & & Lava flows \\
\hline & 29-06-11 & $3 \mathrm{eqh}^{-1}$ & VT HB LP & $\max 2.5$ & CC. $2-12$ & SPORADIC & $?$ & $4-6 \mathrm{~km}$ & ? & Tephra fallout \\
\hline & & & & & & HT max 120 & & & & Lava flows \\
\hline & $30-06-11$ & $1 \mathrm{eqh}^{-1}$ & VT HB LP & $\max 2.9$ & CC., $1.5-8$ & CT, MAX 3 & ? & $4-6 \mathrm{~km}$ & ? & Tephra fallout \\
\hline & & & & & & & & & & Lava flows \\
\hline
\end{tabular}




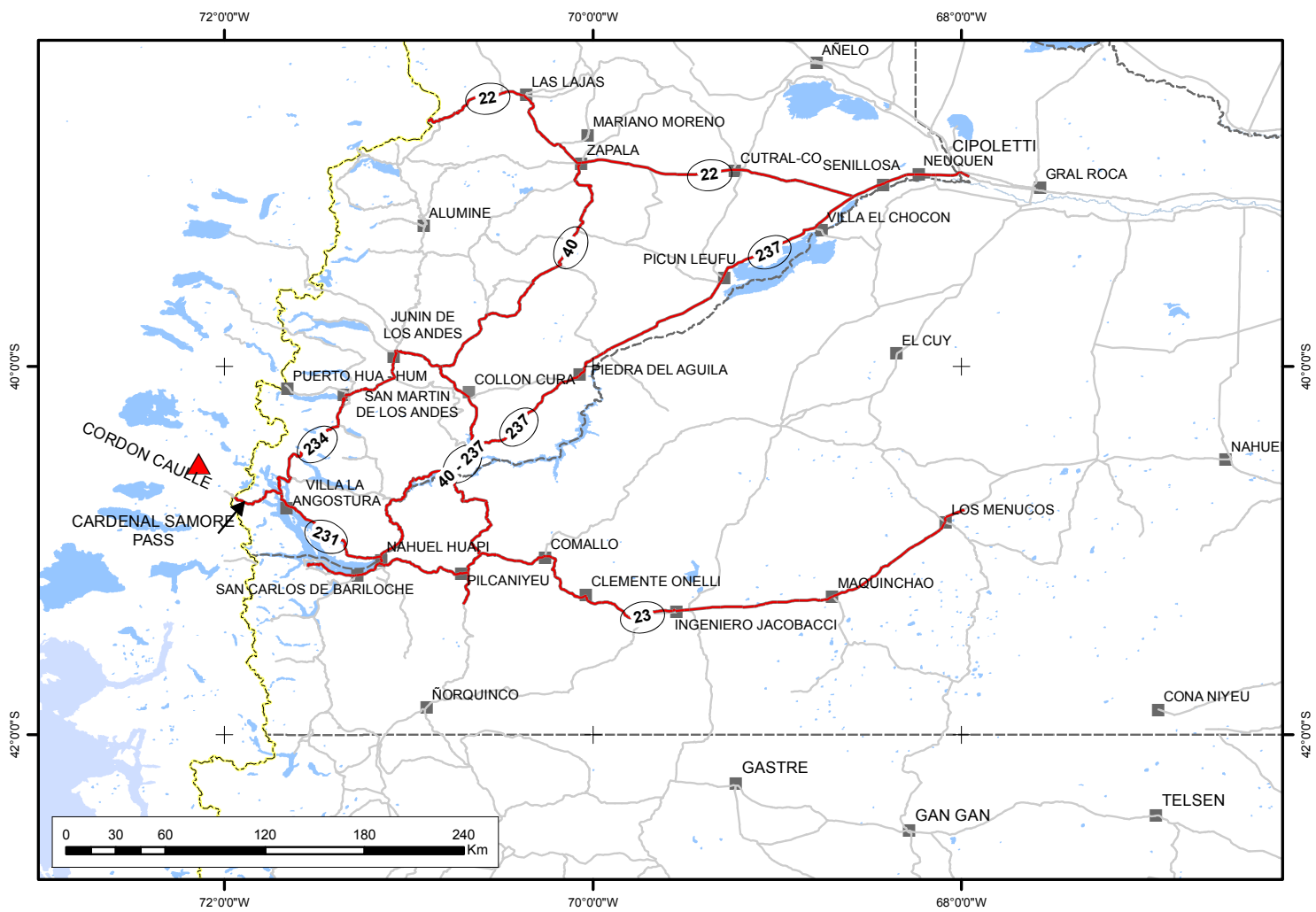

Figure 3. Map showing the main towns and the most affected road sections (red lines) in Neuquén and Río Negro provinces (Argentina) during the Cordón Caulle eruption. The black arrow indicates the international pass Cardenal Samoré

20:00 UTC, large explosions occurred associated with a column height up to $10 \mathrm{~km}$ a.s.l. (Table 2).

The direction of dispersal shifted again to the NE on 12 June. In Villa La Angostura, ash fell together with rain, aggravating the situation due to electric shortage and flooding. Explosions started to become more frequent.

On 13 June, OVDAS reported a change in eruptive activity characterized by episodes of increasing and decreasing tremor associated with changes of plume height. Ash fell in Bariloche, Villa La Angostura up to the "Línea Sur", also affecting a large part of the province of Buenos Aires and of southern Uruguay. Oscillations of the eruptive column were accompanied by ballistic ejection, with bombs reaching distances up to $1 \mathrm{~km}$ from the crater. Direct visual observations revealed a crater with a diameter of 300$400 \mathrm{~m}$ (SERNAGEOMIN-OVDAS, 2010-2012). Oscillating activity continued throughout 14 June with the high-intensity events being characterized by very dense dark eruption column with heights up to $11 \mathrm{~km}$ a.s.l. and lightning observed overnight. Sporadic formation of PDCs travelling down the Nilahue River was also reported.

During 15 and 16 June, a continuous harmonic tremor occurred, suggesting a slow rise of magma along the conduit, which was shortly followed by outpouring of lava from the crater. The lava flow went westward from the pumice cone generated during the first phase of the eruption (Bertin et al., 2012; Tuffen et al., 2013). The harmonic tremor stopped on 23 June, when the alert level was lowered to minor eruption (Table 2). During the rest of June, the plume height varied between 4 and $6 \mathrm{~km}$ a.s.l. Winds mainly dispersed ash over Argentina, except on 22, 23, 25 and 26 June, when the cloud was directed to NNW.

Lava effusion and low intensity ash emission continued for several months. On 22 January 2012 a lahar affected the road 231 near the town of Villa La Angostura. One month later (21 February 2012) another lahar flowed down the Nilhahue river and broke down a bridge. The alert level was lowered to orange on 23 March 2012 and to yellow a month later (23 April 2012), when OVDAS reported ash emission with minor explosions and ash plumes lower than $1 \mathrm{~km}$. In August 2012 the alert level was lowered to green, when OVDAS reported the absence of ash emission, with a gas column lower than $200 \mathrm{~m}$ and residual movements of the lava flows (SERNAGEOMIN-OVDAS, 2010-2012). In January 2013, the lava front was still slowly advancing, despite the lava effusion from the vent had already ceased 6-8 months earlier (Tuffen et al., 2013). 


\section{Evacuation}

\subsection{Chile}

On 4 June, before the beginning of the eruption, ONEMI (Oficina Nacional de Emergencias de Chile) declared a red alert and ordered the evacuation of 710 people from 5 municipalities of Lago Ranco and 6 municipalities from Puyehue area close to the PCCVC (Fig. 1). They also ordered the temporary closure of Paso Cardenal Samoré and the evacuation of the customs staff. Once the eruption started, the evacuation was extended to about 3700 people including localities in the municipalities of Río Bueno, followed by the evacuation of 500 people from the area of Nilahue in the morning of 6 June (Fig. 1).

On 19 June, based on the information released by SERNAGEOMIN, the localities of Lago Ranco municipality (Fig. 1) were considered safe and residents were allowed to return. Conversely, the areas close to the upper part of Nilahue river and its branches were still considered under the threat of potential lahars and floods, the zones $<10 \mathrm{~m}$ above the river level remained forbidden. In total, $\approx 4300$ people were evacuated for 16 days, with a large part hosted by family members living in safe zones and $\approx 600$ lodged in shelters in the regions of Los Ríos and Los Lagos (Abumohor and Díaz, 2011).

\subsection{Argentina}

On 4 June, the Civil Protection of Argentina also declared the red alert, and the border police evacuated the customs staff still present at Paso Cardenal Samoré. Once the eruption started, 27 families living close to Nahuel Huapi lake and its branches received the evacuation order. 20 families were evacuated and relocated with relatives and friends, while 7 decided to remain in order to look after the livestock. Although coast guards and national park personnel attempted to rescue them, the thick raft of pumices in the lake damaged the boats, hampering the operations until 9 June. According to the media, 14 families were also evacuated close to Ingeniero Jacobacci, but official data are not available. Due to shortage in the electrical system and drinkable water, between 3000 and 4000 inhabitants spontaneously evacuated Villa La Angostura during the first weeks of the eruption. On 6 June, 30 vehicles leaving Villa La Angostura were trapped in Collón Curá due to the high concentration of ash in the air (Fig. 3).
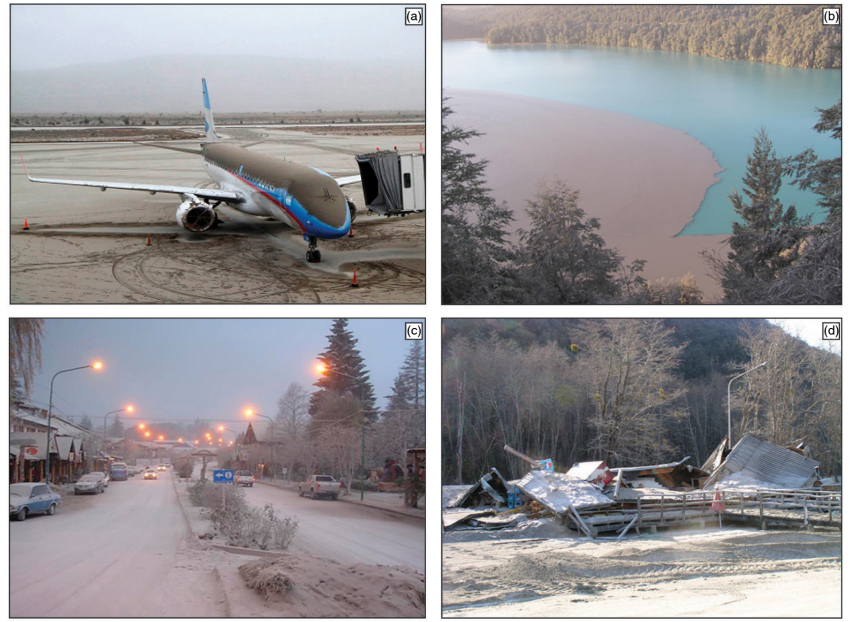

Figure 4. (a) Airplane covered with volcanic ash in Bariloche airport (photo Reuters); (b) Lake Espejo covered with lapilli-size pumice; (c) view of the main street from Villa La Angostura town covered with ash and lapilli, few days after the eruptive climactic phase (Photo Diario de Río Negro, 15 June: http://www.rionegro. com.ar/diario); (d) collapsed tin roof of a restaurant in the area of Paso Samoré.

\section{Impact on transport systems}

\subsection{Air traffic}

The eruption affected the air traffic during several months. On 4 June, the airport in Bariloche was closed and all the flights were cancelled (Fig. 4a). The airport remained closed for 7 months, reopening only in January 2012. On 5 June most flights to Patagonia were cancelled and the airports of San Martín de los Andes, Esquel, Neuquén, Comodoro Rivadavia, Puerto Madryn and Viedma (located 79, 281, 390, 642,700 and $773 \mathrm{~km}$ from vent, respectively), were closed. On 6 June, when ash was dispersed to the north, all flights to San Rafael, Mendoza, Santiago de Chile were cancelled and services in Chile, Uruguay and Brazil were also paralyzed. On 9 June, the airports of Buenos Aires $(1380 \mathrm{~km}$ from vent), Montevideo ( $1540 \mathrm{~km}$ from vent), Punta del Este $(1630 \mathrm{~km}$ from vent) and Puerto Alegre $(2220 \mathrm{~km}$ from vent) were closed for 1 day. On 11 June flights to Tasmania and New Zealand were cancelled, and on 12 June, the airports of Buenos Aires and Montevideo were closed again. On 18 June, the ash had already circumnavigated the globe reaching the locality of Coyhaique in Chile, causing a cancellation of all flights to the south of Chile. Data from the media are summarized in Table 3, including the number of airports and flights cancelled for the month of June. Most flights were cancelled in June, with a few also in July. Other cancellations occurred on 16 October (Buenos Aires), 20 October (Mendoza and San Juan), 22 November (Buenos Aires) and 16 January 2012 (Bariloche). 
Table 3. Summary of number of closed airports and flights cancelled for the month of June 2011.

\begin{tabular}{|c|c|c|}
\hline Date & Closed airports & Cancelled flights, destinations and number \\
\hline 4 Jun 2011 & Bariloche & From Buenos Aires to Patagonia \\
\hline 5 Jun 2011 & $\begin{array}{l}\text { Bariloche, Neuquén, San Martín de los Andes, } \\
\text { Esquel, Viedma, Comodoro Rivadavia } \\
\text { and Puerto Madryn }\end{array}$ & \\
\hline 6 Jun 2011 & $\begin{array}{l}\text { Bariloche, Neuquén, San Martín de los Andes, } \\
\text { Esquel, Trelew, Viedma, Bahia Blanca, } \\
\text { Comodoro Rivadavia and Puerto Madryn }\end{array}$ & $\begin{array}{l}70 \text { flights to Río Gallegos, Río Grande, Ushuaia, Comodoro Rivadavia, } \\
\text { Santa Rosa, San Rafael, Mendoza and Santiago de Chile. } \\
\text { Services paralyzed in Uruguay, Paraguay, Chile y Brazil }\end{array}$ \\
\hline 7 Jun 2011 & $\begin{array}{l}\text { Bariloche, Neuquén, San Martín de los Andes, } \\
\text { Neuquén, Esquel, Trelew, Viedma, Bahia Blanca }\end{array}$ & $\begin{array}{l}62 \text { flights cancelled in Jorge Newbery airport and Ministro } \\
\text { Pistarini International Airport. Flights cancellations } \\
\text { in Montevideo, Santiago de Chile and Brazil. }\end{array}$ \\
\hline 8 Jun 2011 & $\begin{array}{l}\text { Bariloche, Neuquén, San Martín de los Andes, } \\
\text { Neuquén, Esquel, Trelew, Viedma, Bahia Blanca }\end{array}$ & \\
\hline 9 Jun 2011 & $\begin{array}{l}\text { Bariloche, Neuquén, San Martín de los Andes, } \\
\text { Neuquén, Esquel, Trelew, Viedma, } \\
\text { Bahia Blanca, Puerto Madryn }\end{array}$ & $\begin{array}{l}305 \text { flights cancelled in Jorge Newbery and } \\
\text { Ministro Pistarini airports. Most of the flights } \\
\text { cancelled in Carrasco International Airport Uruguay. } \\
\text { Cancellation in Paraguay and Brazil. }\end{array}$ \\
\hline 10 Jun 2011 & Bariloche, Neuquén, San Martín de los Andes & $\begin{array}{l}\text { Flights to Patagonia cancelled. } \\
\text { Resume flights from Buenos Aires until 19:00 (LT). }\end{array}$ \\
\hline 11 Jun 2011 & Bariloche, Neuquén, San Martín de los Andes & Flights to Patagonia cancelled. \\
\hline 13 Jun 2011 & Bariloche, Neuquén, San Martín de los Andes & $\begin{array}{l}\text { Flights cancellation in Jorge Newbery and } \\
\text { Ministro Pistarini airports during the morning. }\end{array}$ \\
\hline 14 Jun 2011 & $\begin{array}{l}\text { Bariloche, Neuquén, } \\
\text { San Martín de los Andes, La Pampa }\end{array}$ & \\
\hline 15 Jun 2011 & & $\begin{array}{l}\text { Aerolineas Argentinas airline suspended flights to Patagonia, } \\
\text { Mendoza and south Buenos Aires }\end{array}$ \\
\hline 24 Jun 2011 & & $\begin{array}{l}\text { Aerolineas Argentinas airline suspended flights that departure } \\
\text { from Jorge Newbery and Ministro Pistarini airports. Since 17:30 (LT) } \\
\text { all the flights were suspended in Jorge Newbery airport }\end{array}$ \\
\hline 25 Jun 2011 & & $\begin{array}{l}\text { Flights cancellation in Jorge Newbery and Ministro Pistarini } \\
\text { airports during the afternoon. }\end{array}$ \\
\hline 26 Jun 2011 & & Flights cancellation in Jorge Newbery and Ministro Pistarini airports. \\
\hline 27 Jun 2011 & & Flights cancellation in Jorge Newbery and Ministro Pistarini airports. \\
\hline 28 Jun 2011 & $\begin{array}{l}\text { Esquel, Comodoro Rivadavia Mar del Plata } \\
\text { and Bahia Blanca }\end{array}$ & Flights cancellation in Jorge Newbery and Ministro Pistarini. \\
\hline
\end{tabular}

\subsection{Roads and navigation}

The international pass Cardenal Samoré, commonly used by trucks carrying products to southern Chile, was closed from the beginning of the eruption, reopening on 2 September 2011 to small and medium vehicles only. Between 1 October and 15 December, assisted passage of trucks was authorized during the evening hours (from 21:00 to 06:00) in order to reduce ash remobilization during the day. National, provincial and local roads were also affected by ash fall. On 4 June, Routes 234 ("Camino de los 7 Lagos") and 231 in the section between Villa La Angostura and the international border were closed. It was also recommended to avoid Route 40 and 231 between Villa La Angostura and Bariloche (Fig. 3).

During the course of the eruption, numerous routes, where concentration of ash was high and visibility low, in the provinces of Neuquén and Río Negro were closed at night or during the days (Fig. 3, Table 4). Ash covering the asphalt caused additional problems such as hiding of the demarcation lines and hampering of ice melting during the winter season. Daily reports recommended people to drive with extreme caution due to low visibility, slippery roads and intense ash re-suspension. Cleaning operations of routes, mainly of 
Table 4. List of the routes in Neuquén and Río Negro provinces closed during CC eruption (see also Fig. 3).

\begin{tabular}{ll}
\hline Road no. & Section \\
\hline 231 & Cardenal Samoré Pass-Villa \\
& La Angostura-Intersection Route 40 \\
234 & "Camino de los 7 Lagos" \\
234 & Junín de los Andes-Rinconada \\
40 & Bariloche-Piedra del Aguila \\
40 & Neuqén-Bariloche \\
40 & Catan Lil-Zapala \\
40 & Zapala-Junín de Los Andes and San Martín \\
237 & Collón-Curá \\
237 & Bariloche-Piedra del Aguila \\
23 & "Línea Sur", Río Negro \\
22 & Arroyito-Zapala \\
\hline
\end{tabular}

the stretch towards the international boundary, also disrupted and interrupted the traffic on several occasions.

The humid climate of the Andes, combined with the high availability of tephra and rugged topography, favoured the development of lahars and flooding of roads. Two lahars affected the international road 231, one close to the International border and the other in the vicinity of Villa La Angostura. On 10 June, a lahar locally interrupted a route near Villa Traful. Street flooding and paralyzed vehicles were reported on 9 and 10 June in Villa La Angostura.

Due to the accumulation of tephra on Lake Nahuel Huapi and on its various branches (Fig. 4b), the Naval Prefecture banned the navigation and closed lake ports. The pumice raft, which according to the media reached thickness between 12 and $30 \mathrm{~cm}$, damaged the boat engines.

\section{Tourism}

Tourism (national and international) is the most important source of income in Villa La Angostura, Bariloche and San Martín de los Andes. As a result, the economic impact of the eruption was significant during both winter 2011 and summer 2012 mainly due to the following: (i) air traffic restrictions in Bariloche, Neuquén and San Martín de los Andes airports (ii) regulation of the land access to these areas and (iii) cuts in electric power. About $80 \%$ of hotel reservations were cancelled in Bariloche during the second week of the eruption. Ski resorts of Cerro Bayo (Villa La Angostura) and Cerro Catedral (Bariloche) were covered by ash, damaging infrastructures such as lifts. 900 small enterprises and 3500 job places were threatened, and the Chamber of Commerce estimated a loss of ARS 200 million (nearly USD 48 million). Tourism decreased by $\sim 52 \%$ in the Neuquén region and by $\sim 37 \%$ in the Río Negro region with respect to the previous year, causing a total loss of ARS 800 million (about USD 187 million) due to hotel cancellations only (Barbier, 2012).

\section{Impact on communities}

Urban systems were impacted at different levels, as described in the following sections and summarized in Table 5.

\subsection{Urban areas}

The areas most affected by ash fallout included southern Neuquén province and south-central Río Negro, as well as northern Chubut (Fig. 3). Among the most affected localities are Villa La Angostura, Villa Traful, Bariloche and others located in the Línea Sur (Ingeniero Jacobacci, Maquinchao, Los Menucos, Pilcaniyeu and Comallo).

The impact on urban areas and infrastructures varied depending on the distance from the vent and from the average position of the plume axis (e.g. ash thickness and grain size), weather conditions and topography of the affected area (Tables 5,6 ). Intense tephra fallout (that produced a 10-12 cmthick deposit) in Villa La Angostura caused blackouts and cuts of water supply, obstruction of streets, ash accumulation on roofs and problems for daily activities over a long period due to ash re-suspension (Fig. 4c). Moreover, in this area which is characterized by high relief and abundant availability of water, lahars were frequently generated. After the first days of the eruption, a warning was raised in Villa La Angostura about the possibility of generation of lahars triggered in the upper catchment of the area. The COE (emergency committee) reported 64 houses located on the fan and the river terraces exposed to lahars. Low, wet areas close to the lake "Mallin" (old delta deposits) also experienced flooding.

Between 7 and 10 June, floods occurred in Bariloche, following $30 \mathrm{~mm}$ of rain in the urban area and $10 \mathrm{~cm}$ of snow on the neighbouring hills, affecting several houses and educational establishments. Bariloche was also affected by $2-$ $5 \mathrm{~cm}$ of ash fallout. In the southern part of the province of Río Negro, ash thickness varied between 3 and $8 \mathrm{~cm}$ (Table 7).

\subsection{Disruption of communications and public activities}

During the first few weeks of the eruption, communications (fixed, mobile or Internet telephony) were interrupted at various locations. In Villa La Angostura and Bariloche, shops, supermarkets and gas stations were saturated, causing shortages of fuel and masks. Schools, public offices and even shops and banks remained closed in numerous localities. In Villa La Angostura, classes and public administration were immediately suspended as the eruption started. Due to tephra accumulation making streets impracticable, shops were closed and public transports were interrupted.

On 6 June, both classes and commercial activities were suspended in Bariloche, leaving only supermarkets and gas stations open, sourcing power through generators. Activities were resumed after 3 days, except for educational institutions that suffered some disruptions. Subsequently, discontinuous interruption of classes and public activities occurred during 
Table 5. Different types of impacts in urban areas and relative duration, as reported in the media (see references in Appendix A). ${ }^{* * * *}$ : first month; ${ }^{* * *}$ : first 2 weeks; ${ }^{* *}$ : first week; ${ }^{*}$ : sporadic.

\begin{tabular}{|c|c|c|c|c|c|c|c|c|c|c|}
\hline & $\begin{array}{l}\text { Villa La } \\
\text { Angostura }\end{array}$ & Bariloche & $\begin{array}{l}\text { Ingeniero } \\
\text { Jacobacci- } \\
\text { Línea Sur }\end{array}$ & $\begin{array}{l}\text { Villa } \\
\text { Traful }\end{array}$ & $\begin{array}{c}\text { San Martín } \\
\text { de Los } \\
\text { Andes }\end{array}$ & $\begin{array}{c}\text { Río } \\
\text { Negro } \\
\text { Valley }\end{array}$ & $\begin{array}{l}\text { Piedra } \\
\text { del } \\
\text { Aguila }\end{array}$ & Chubut & $\begin{array}{c}\text { Río } \\
\text { Negro, } \\
\text { Atlantic } \\
\text { Coast }\end{array}$ & $\begin{array}{c}\text { La } \\
\text { Pampa }\end{array}$ \\
\hline Disruption of electric supply & $\mathrm{X}^{* * * *}$ & $\mathrm{X}^{* * *}$ & $\mathrm{X}^{* *}$ & $\mathrm{X}^{* *}$ & $\mathrm{X}^{* *}$ & & & & & $\mathrm{X}^{* *}$ \\
\hline Water supply & $\mathrm{X}^{* * * *}$ & $\mathrm{X}^{* * *}$ & $\mathrm{X}^{* *}$ & $\mathrm{X}^{* *}$ & $\mathrm{X}^{* *}$ & & & & & \\
\hline Obstructions of drainage systems & $\mathrm{X}^{* *}$ & $\mathrm{X}^{* *}$ & $\mathrm{X}$ & & & & & & & \\
\hline Disruption of communications & $\mathrm{X}^{* * *}$ & $\mathrm{X}^{* * *}$ & $\mathrm{X}^{* * *}$ & $\mathrm{X}^{* *}$ & & & & & & $\mathrm{X}^{* *}$ \\
\hline Disruption of road traffic & $\mathrm{X}^{* *}$ & & $\mathrm{X}^{* * *}$ & $\mathrm{X}^{* *}$ & & & & & & \\
\hline Roof collapse & $\mathrm{X}^{* * *}$ & $\mathrm{X}^{* * *}$ & & & & & & & & \\
\hline Disruption of navigation & $\mathrm{X}^{* * *}$ & $\mathrm{X}^{* * *}$ & & $\mathrm{X}^{*}$ & & & & & & \\
\hline Isolation of towns and people & $\mathrm{X}^{* * *}$ & $\mathrm{X}^{* * *}$ & $\mathrm{X}^{* * *}$ & $X^{* *}$ & & & & & & \\
\hline $\begin{array}{l}\text { Saturation of gas stations, } \\
\text { supermarkets and drugstores }\end{array}$ & $\mathrm{X}^{* *}$ & $\mathrm{X}^{* *}$ & $\mathrm{X}^{* *}$ & & & & & & & \\
\hline $\begin{array}{l}\text { Suspension of school and } \\
\text { administrative activity }\end{array}$ & $\mathrm{X}^{* * *}$ & $\mathrm{X}^{* * *}$ & $\mathrm{X}^{* * * *}$ & $\mathrm{X}^{* *}$ & $\mathrm{X}^{* *}$ & $\mathrm{X}^{* *}$ & $\mathrm{X}^{* *}$ & $\mathrm{X}^{* *}$ & $\mathrm{X}^{* *}$ & $\mathrm{X}^{* *}$ \\
\hline
\end{tabular}

Table 6. Distance from vent and population of towns and settlements affected by tephra fallout.

\begin{tabular}{|c|c|c|c|}
\hline Towns/settlements & Province & Distance from vent $(\mathrm{km})$ & Population (number of inhabitants) \\
\hline Villa La Angostura & Neuquén & 48 & 11063 \\
\hline Villa Traful & Neuquén & 65 & 417 \\
\hline San Martín de Los Andes & Neuquén & 79 & 28599 \\
\hline Junín de Los Andes & Neuquén & 111 & 13086 \\
\hline Piedra del Aguila & Neuquén & 184 & 3689 \\
\hline Neuquén & Neuquén & 390 & 231780 \\
\hline Zapala & Neuquén & 254 & 32355 \\
\hline San Carlos de Bariloche & Río Negro & 98 & 112887 \\
\hline Pilcaniyeu & Río Negro (Línea Sur) & 136 & 757 \\
\hline Comallo & Río Negro (Línea Sur) & 168 & 1497 \\
\hline Clemente Onelli & Río Negro (Línea Sur) & 194 & 114 \\
\hline Ingeniero Jacobacci & Río Negro (Línea Sur) & 237 & 6261 \\
\hline Maquinchao & Río Negro (Línea Sur) & 300 & 2494 \\
\hline Los Menucos & Río Negro (Línea Sur) & 344 & 5187 \\
\hline Cona Niyeu & Río Negro & 461 & 217 \\
\hline Río Colorado & Río Negro & 711 & 13828 \\
\hline San Antonio Oeste & Río Negro & 609 & 21643 \\
\hline Sierra Grande & Río Negro & 582 & 7641 \\
\hline Viedma & Río Negro & 773 & 53618 \\
\hline General Roca & Río Negro & 426 & 90607 \\
\hline Cipolletti & Río Negro & 397 & 85161 \\
\hline Gastre & Chubut & 310 & 602 \\
\hline Gan Gan & Chubut & 390 & 661 \\
\hline Telsen & Chubut & 482 & 544 \\
\hline Dolavon & Chubut & 617 & 3307 \\
\hline Gaiman & Chubut & 631 & 6627 \\
\hline Rawson & Chubut & 660 & 31787 \\
\hline Trelew & Chubut & 642 & 99430 \\
\hline Puerto Madryn & Chubut & 642 & 81995 \\
\hline Puerto Pirámides & Chubut & 693 & 565 \\
\hline
\end{tabular}

the days of ash fall and depending on the state of electric and water supplies. Health centres and hospitals suspended scheduled appointments and attended only emergency opera- tions during days of high concentration of ash in suspension. By 19 June only 16 schools out of 65 could return to normal activity because cleanup was not completed. 
Table 7. Comparison of thickness of tephra fallout as reported in the media and measured in the field (Pistolesi et al., 2015).

\begin{tabular}{lccccc}
\hline Locality & $\begin{array}{c}\text { Distance } \\
\text { from vent }(\mathrm{km})\end{array}$ & $\begin{array}{c}\text { Maximum thickness } \\
\text { reported }(\mathrm{cm})\end{array}$ & \multicolumn{3}{c}{$\begin{array}{c}\text { Measured thickness } \\
(\mathrm{cm})\end{array}$} \\
\cline { 3 - 6 } & & & June-July 2011 & November 11 & April 2012 \\
\hline Paso Samoré & 27 & 20 & 45 & 37 & - \\
Villa La Angostura & 48 & 30 & 12.5 & 12.8 & 12.5 \\
Bariloche & 98 & 5 & 2 & - & - \\
Ingeniero Jacobacci & 237 & 15 & 3.8 & - & - \\
Maquinchao-Los Menucos & $300-344$ & 4 & 3.5 & - & - \\
Villa Traful & 65 & 10 & - & - & - \\
San Martín de Los Andes & 79 & 2 & - & - & - \\
Piedra del Aguila & 184.2 & - & & - \\
Gastre & 310 & 4 & & & - \\
\hline
\end{tabular}

On 6 June, classes and public activities were also suspended in Ingeniero Jacobacci. Shops were closed and health centres restricted to emergencies. At the local hospital, surgery was suspended because of the large amount of ash inside the building. On 10 June, commercial and public services were resumed, but schools remained closed. In the nearby towns, such as Los Menucos and Maquinchao, due to thinner ash deposit and strong winds, schools resumed classes during the second week of the eruption.

Classes and administrative activities were also suspended in more distal locations. In San Martin de Los Andes, classes were suspended for a week and public activity was minimized. Health centres and hospitals continued working normally, and only scheduled surgeries were suspended. In Piedra del Aguila, classes and public activities were suspended on 6 June. In the Upper Valley of Río Negro, in the towns of General Roca and Cipolleti, classes in schools and universities were suspended on 7 and 8 June, when the plume was dispersed to NNE. In Chubut, 20 towns and settlements in the centre and north of the province suspended classes on 6 June. These classes resumed on 10 June with the exception of schools in rural communes.

In the eastern province of Río Negro, the municipalities of Sierra Grande, Río Colorado and Cona Niyeu suspended classes for a week because of ash and strong winds. In the province of La Pampa, classes were suspended on 9 June. During the first week, the meeting of ministers of Economy of the UNASUR (Unión de Naciones Sudamericanas - South American Nations Union) that was supposed to be held in Buenos Aires was also cancelled.

\subsection{Isolation of towns and settlements}

Disruption of land and water traffic isolated towns and settlements. On the outskirts of Villa La Angostura, people living on the coast of Brazo Rincon lake (about 70 people) were isolated due to impracticable roads and impossibility of lake navigation. At the beginning of the eruption about 20 families were evacuated, but others remained isolated and suf- fered from shortage of drinkable water and food for livestock. In Bariloche, 50 people were stranded on Victoria Island by the impossibility of navigation on Nahuel Huapi lake, and were rescued by the coast guard only on 9 June. Isolated people were also reported in smaller towns around Bariloche. In Villa Traful, the municipality managed to provide inhabitants of the opposite side of the lake who remained in their homes with food and water.

Between 5 and 9 June, the towns of the Línea Sur remained isolated due to the closure of the routes due to poor visibility. In addition to the closure of the routes, drivers avoided using vehicles to prevent damage due to ash, including clogging of air filters. Between 7 and 9 June, a wind storm exacerbated the situation hindering the supply of vital products and the arrival of aids from the national and provincial government. Around Ingeniero Jacobacci, families and indigenous communities were isolated, suffered water shortages and were forced to remain in their houses due ash storms caused by strong winds. Road traffic was forbidden and people were recommended to stay at home, and to go out only in case of emergencies using goggles and masks.

\section{Impact on infrastructures and lifelines}

\subsection{Electric system}

The electric supply was damaged since the start of the eruption in almost all localities affected by ash fallout, causing cascading problems to water supply, trade and educational and administrative activities. Supply failures had different causes, including ash accumulation on the network, damage to substations, power plant failures due to falling of both trees and poles and lightning. As a consequence, energy companies had to schedule additional interruptions for cleaning and maintenance purposes. In Villa La Angostura, blackouts began during the first week of the eruption and lasted for 1 month. On 8 June, widespread ash fallout mixed with rain- 
water caused cut-offs due to wet ash deposition on the insulating lining.

According to the director of Villa La Angostura EPEN (Provincial Agency for Energy of Neuquén), during the first days of the eruption, services were restored only in strategic areas, such as hospitals, fire-fighter stations and crisis committee meeting sites. Continuous power outages lasted until 24 June (with $40 \%$ of the town without power), followed by sporadic events after June.

Causes of energy cut-offs in Villa La Angostura included failures of the power plant, transformer stations and insulation of the power lines, particularly during days of falling ash and rain (e.g. 8, 9 June). The EPEN scheduled power cuts for cleaning low voltage lines, and simple protection measures with PVC pipes solved problems due to the adhesion of ash on the conductors of the electrical system.

In Bariloche, cuts in the electricity supply were also recorded from the beginning of the eruption, including the Alicurá-Bariloche high-voltage $132 \mathrm{kV}$ power plant. Reported power cut-offs were more frequent during the first and second week of the eruption, later occurring sporadically. On 6 June, the ash fall mixed with rain caused cuts in the transformer station of Bariloche (La Paloma). In the morning of 7 June, a massive blackout of more than $12 \mathrm{~h}$ was reported in town.

In the Línea Sur, power failures were also reported. On 8 June, a heavy windstorm hit the area, causing power outages caused by accumulation of remobilized ash on highvoltage masts. After the first week of the eruption electric cuts were sporadic. In Villa Traful, problems on the power supply were reported since the first ash fallout episodes on 5 June.

\subsection{Water and drainage systems}

Tephra fallout also affected the water supply at various locations. In areas where the water intakes are in open courses, the service was interrupted due to the high amount of suspended material. At sites where the sockets were located on the lake, tephra clogged pumps and filters, and temporary water shortages occurred during maintenance operations, such as replacing pumps. In some cases, cuts in water service were directly related to power outages.

In Villa La Angostura the media reported water cuts since the beginning of the eruption and, by 9 June, water service was interrupted in the neighbourhoods located at higher elevations. The EPAS (Provincial Agency for Water and Sanitation) replaced pumps and performed maintenance and cleaning operations of the water intakes and, from 20 June, the service was restored in most of the town, except in Puerto Manzano (port in Villa La Angostura), where the intakes are on the surface of the lake. Intakes located in the rivers of Bonito (south of town) and Correntoso (north of town) were closed due to the high amount of floating and suspended material. EPAS conducted monitoring of drinking water qual- ity and found no toxicity. In Bariloche, where most intakes are located on the lake and to a lesser extent in streams and springs, the increase of suspended material required an increase in maintenance. On 9 June, a breakdown of the system occurred, and the municipality distributed drinking water to the population. Supply disruptions were also reported for the neighbourhoods at higher elevations that depend on intakes in springs or streams. The Provincial Department of Water performed analyses to warrant drinking-water qualities. In the Línea Sur, problems with water supply were related to electricity breakdown. In Villa Traful water supply was also disrupted because $90 \%$ of drinking water comes from streams, leading to increase turbidity and temporary closure of water intakes, to avoid abrasion and clogging. In San Martin de Los Andes, the Provincial Department of Water suspended water intake in the river Quilquihue, and the storage tanks were used for supply.

In Villa La Angostura and Bariloche, obstruction of urban drainage systems occurred during rainy days because waterindurated ash deposited on the streets. Municipality teams used dedicated machinery to remove the ash. At the beginning of the eruption Villa La Angostura received assistance from other municipalities because they had no proper machineries and staff to clean the roads (see the Management section for more details).

\subsection{Roof collapse}

Collapse of roofs occurred in Villa la Angostura, Bariloche and Brazo Rincon (northern limit of Nahuel Huapi Lake) but with no associated injuries or casualties. On 8 June, a whole restaurant collapsed in the area of Paso Samoré, partially due to poor construction (i.e. thin roofs, wooden structure; Fig. 4d). In Bariloche, roof collapses were mainly reported in the poorest neighbourhoods, such as "El Alto Bariloche". After 14 days from the beginning of the eruption, 147 houses made of metal and wood were significantly affected. The ceiling of a school also collapsed, but it was not clear if this occurred due to the accumulation of ash.

\section{Impact on animals}

\subsection{Livestock}

The Cordón Caulle eruption intensified the crisis that had been affecting the livestock sector since 2007 due to persistent drought. This resulted in loss of animals, low birth rate and high predation. A few days after the beginning of the eruption, ash had already covered grass and water pools causing a shortage of water and forage for the animals. Ash re-suspension also disorientated animals that could not feed anymore. The most affected departments in the province of Neuquén were those located between the Cordillera and the extra-Andean Patagonia. The total number of animals at the moment of the eruption, including sheep, goats and cattle, 
was 149000 . Given that livestock producers depend on the forest to feed their animals and that many producers had no reserves, the mortality rate for animals was high due to lack of food and was estimated at $22 \%$ (number of animals; Anselmi et al., 2012). The southwest departments of Río Negro province (INTA-EEA, 2011) were the most impacted in terms of number of producers and of animals affected (total of 1400 farmers who raise sheep, cows and goats). The decrease in the production of wool and the loss of animals varied according to the amount of accumulated ash (Fig. 5a). The areas with the largest impact were those suffering ash accumulation thicker than $3 \mathrm{~cm}$, where accessibility to forage was low. Finally, livestock in the departments located in the northern sector of Chubut province was also affected. In these areas, ash accumulation varied between 0.3 and $4 \mathrm{~cm}$ (INTA-EEA Chubut, 2011).

Reported problems to livestock included eye irritation, difficulties in breathing and digestion. In many places, an accelerated aging of the flocks by the wear of the teeth of animals was observed (Giraudo and Villagra, 2011). These factors contributed to the reduction in the income of producers, most of whom depended on complementary feeding for animals provided by National, Municipal governments and INTA (National Institute of Agricultural Technology). Animals ingested large amounts of ash in areas where the grass was covered. The ash accumulation and passage through the digestive tract of animals produced alterations of different types. The presence of ash was detected in the digestive tract in sheep and by observed changes in the colour of the mucosa or inner wall of the digestive organs (Robles, 2011). In the case of sheep, the change in diet, generated by the ash fallout, plus supplementation with forage and implemented grains, possibly triggered early outbreaks of enterotoxemia (enteric and septicaemia disease caused by different types of Clostridium perfringensand its toxins). Cases of diarrhoea and sudden death were reported for cattle, but it is not clear whether they were due to direct action of the ash or to an infectious disease. For horses, colics and subsequent death were reported (Robles, 2011).

\subsection{Fish}

After the eruption, research groups of the Instituto de Investigaciones en Biodiversidad y Medioambiente (INIBIOMA, CONICET - Comahue, 2012) carried out a study on the water ecosystem. One year after the eruption, they observed that even though the impact of ash on fish populations was variable, the microorganisms were the most affected. They analyzed samples from the lakes Espejo, Correntoso and Nahuel Huapi, close to Villa La Angostura. As a consequence of the eruption, the lakes were covered by lapilli-sized pumice clasts, while volcanic ash remained suspended in the water body. Microorganisms living in these lakes are well adapted to extreme light conditions and low level of nutrients. However, as the ash lowered the amount of light and ultravio-
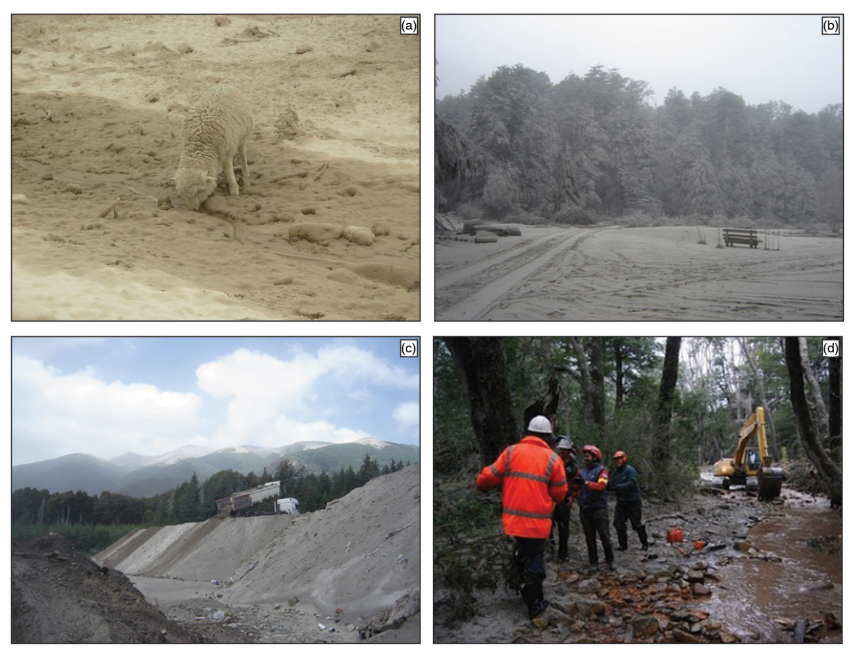

Figure 5. (a) Sheep covered with ash near Ingeniero Jacobacci (photo Diario de Río Negro, http://www.rionegro.com.ar/diario/); (b) Villa La Angostura Forest covered with tephra in June 2011; (c) over a million cubic metres of volcanic ash and lapilli were stocked in an old quarry; (d) army and fire management volunteers cleaning the channels in order to mitigate lahars (photo http: //www.minutoneuquen.com).

let radiation, filter feeders were drastically reduced. Since these organisms are the intermediate links in the food chain, some effects could be expected at higher levels. With respect to fish, ash had two different consequences. Native populations were mostly affected in terms of displacement of young members from the most affected coastal areas to the open waters, with lower concentration of ash but less protected. According to INBIOMA, native species, such as the "puyen grande" (Galaxiidae) and the "peladilla" (Aplochiton zebra), are adapted to turbidity in the water as a result of ash fallout. In the case of introduced species, like salmon and trout, the effects were different. Salmons typically spawn under the gravel of the bed of mountain streams; sedimentation between 5 and $40 \mathrm{~cm}$ of ash buried those niches and prevented the development of embryos, which caused the disappearance of some fish generations. On the other hand, farmed rainbow trout ingested a lot of ash due to similarity with the typical food (i.e. pelleted feed).

\subsection{Stags}

Between 3 July and 14 September 2011, the Hunt responsible of the Nahuel Huapi National Park conducted a field investigation of 9 female red deer (Cervus elaphus), with ages ranging from birth until 8 years of life. Notably, no studies were carried out on indigenous protected species, such as pudú, huemul and guanaco. The studied animals lived in the transition zone between forest and steppe, between 850 and $1600 \mathrm{~m}$ a.s.l., both on private property and public lands. The area, according to recent studies, is home to the highest den- 
sity of red deer (109 deer per 100 acres). In each case, a field necropsy was carried out. The general condition of the animals showed no unusual features except for a significant thinness that was not expected after a mild winter, although immediately after the ash fall red deer in the area had a state of confusion and unusual meekness (Méndez Guerrero, 2011). Such thinness could be attributed to a reduction in the food supply. Weights of fetuses were also below normal values. The stomach and intestinal contents observed were normal and no signs of wear to dentures were detected.

\subsection{Insects}

As already observed at other volcanoes (e.g. Mt St Helen, Soufriere Hills, Irazu; Buteler et al., 2011), volcanic ash had an insecticide effect over a broad spectrum of insects. Laboratory tests have demonstrated that the main cause of mortality in insects exposed to volcanic ash is desiccation: the abrasive action of the particles on the insect epicuticle makes it permeable, and, therefore, increases the dehydration of the insect. Other factors that may cause insect mortality are the occlusion of the respiratory organs, excessive salivation, interruption of the digestive activity through the accumulation of ash in the intestine and the massive destruction of vegetation that some species depend on. The extent of the impact of volcanic ash on insect populations varies depending on the composition, degree and duration of exposure and also on the species and the status of the insect. The particle size is an important factor: particles larger than $15 \mu \mathrm{m}$ have limited effect because they do not adhere to the insects. This effect increases with a decreasing particle size, reaching its maximum effectiveness when the equivalent diameter of the pyroclastic material is $2-10 \mu \mathrm{m}$. Ash particles also lose much of their insecticidal power when they are wet due to rain (Buteler et al., 2011).

The insecticidal effect of the Cordón Caulle ash removed much of herbivorous insects, such as grasshoppers, which feed on the vegetation of wet meadows, the main forage resource in the Patagonian steppe. In addition, it affected the bee populations in areas southwest of Río Negro and west of Neuquén, where a total of 1200 hives belonging to smallholders were estimated at the time of the eruption. A bee mortality of more than $70 \%$ was reported (Huerta, 2011). It also decreased the abundance of wasp known as "yellow jacket" ("Chaqueta amarilla", Vespula spp.) in several locations in the mountainous area of Río Negro and Neuquén (Corley et al., 2012).

\section{Impact on vegetation}

A report by botanical experts and researchers from UNC and CONICET (Javier Puntieri and Javier Grosfeld, in Ubeda et al., 2011) emphasizes that "it is a benefit that the eruption occurred at that time of the year when most of the plants have very low metabolic activity". They also stated that the germination of some species for the following spring could be compromised depending on the accumulation of ash and its dispersal. According to the experts, the greatest damage would have been on pastures in steppe area, but tephra could also break fruit buds and the branches of large trees in the forest areas (Fig. 5b).

INTA (Gaitan et al., 2011) conducted seasonal and interannual vegetation monitoring from MODIS image data to detect the effects of ash. The EVI (enhanced vegetation index) is used to characterize bio-physical/biochemical states and processes from vegetated surfaces (Huete et al., 2002). Analyses were performed for three types of vegetation: forests, steppes and wet meadows. They concluded that the ash had a negative initial impact on all the three types of vegetation, proportional to the thickness of ash fall. Gaitan et al. (2011) classified the Neuquén and Río Negro province surface in 10 classes according to the total tephra deposit thickness (from class 1: no ash, to class 10: $15-30 \mathrm{~cm}$ ). In December 2011, forest sectors closest to the volcano kept EVI values between 30 and $35 \%$ below average. The steppes showed initial impact proportional to the amount of ash deposited and in December 2011, even though they had partially recovered, they were between $27 \%$ (class 2) and $37 \%$ (class 6) below the mean for the period 2000-2010. For wet meadows (mallines), the recovery appeared to be associated to geographical location in relation to the level of annual precipitations, varying between 800 and $300 \mathrm{~mm}$ from west to east. Those located in the wettest area regained their activity, while wet meadows located further east were still with values up to $50 \%$ below average.

To assess the impact on steppes, two studies were conducted. The first considered a transect along National Route 23 between Bariloche and Onelli and the second an experiment in the pre-cordillera (Ghermandi and Gonzalez, 2012). They confirmed a general delay in growth, mainly in wet meadows and steppes, expressed in lower forage biomass per unit area (Siffredi et al., 2011). The second study was carried out on grasslands located $30 \mathrm{~km}$ east of Bariloche, where 20 forest clearings, representing sites of biodiversity and safe sites for the reproduction of the matrix species (grass and shrubs; Ghermandi and Gonzalez, 2012), were randomly selected. Species richness was lower after the eruption (24 vs. $17 \%)$, as it was the percentage of annual species (37.5 vs. $6 \%$ ). They concluded that for the study area the impact on vegetation will be important and lasting because the estimated value of accumulated ash on forest clearings of 1 hectare of pasture is high, coupled with the semi-arid climate of the region. 


\section{Impact on health}

\subsection{General well-being}

Although no official study is available, most locations reported increased medical visits for respiratory difficulties, eye problems and stress. At the hospital of Villa la Angostura, although no serious cases were treated, cases of gastritis (possibly related to lack of electricity and food preservation) and conditions related to stress (contractures, various pains, high blood pressure) were also reported. In San Martin de Los Andes, hospital visits for cases of eye irritation increased. On 8 June, the hospital in Cipolleti reported that $80 \%$ of consultations were for bronchospasm, asthma attack and eye irritation. The hospital of Roca reported cases of inquiries for respiratory problems. In Villa La Angostura, Bariloche and San Martin de los Andes, the media also reported psychological impact. The population was alarmed because the lack of information during the first days of the eruption.

Even though cristobalite was reported for the products of the 2008 Chaitén eruption (Reich et al., 2009; Horwell et al., 2010), it was not detected through X-ray diffraction of CC ash (Daga et al., 2014). Wilson et al. (2013) reported a low total amount of cristobalite in the CC ash deposit $(0.21 \pm 0.42 \mathrm{wt} \%)$.

\subsection{Air quality}

Since July, a SEGEMAR team for the control of air quality performed measurements of concentration of suspended particulate materials $\left(\mathrm{PM}_{10}\right.$; equivalent aerodynamic diameter $\leq 10 \mu \mathrm{m}$ ) at various locations (Villa La Angostura, Piedra del Aguila, Ingeniero Jacobacci and San Martín de Los Andes). Due to instrumental limitations, no concentrations of particles smaller than $2.5 \mu \mathrm{m}$ in diameter, $\mathrm{SO}_{2}$ and $\mathrm{NO}_{x}$ were measured. Values established by law 24.585 (Argentine Environmental law on standard air quality, water and soil levels) were taken as reference, indicating maximum levels of $\mathrm{PM}_{10}$ of $150 \mu \mathrm{g} \mathrm{m}^{-3}$ for a $24 \mathrm{~h}$ exposure and $50 \mathrm{\mu g} \mathrm{m}^{-3}$ for an exposure of 1 year. Systematic monitoring of $\mathrm{PM}_{10}$ was carried out for 10 months starting in September 2011 in Villa La Angostura and Ingeniero Jacobacci. The aim of this study was to assess the medium-term effects of ash fall. Two time periods were considered: the first one included determinations carried out 1 month after the eruption onset and for a short time (less than or equal to 1 week) and the second included determinations carried out between September 2011 and July 2012.

As an example, $\mathrm{PM}_{10}$ concentrations are presented in Fig. 6a and $\mathrm{b}$ for Villa La Angostura, representing measurements taken in July 2011 in the hospital and school CPEM68 (Centro Provincial de Enseñanza Media no. 68). In the hospital, the daily exposure limit $\left(150 \mu \mathrm{g} \mathrm{m}^{-3}\right)$ was exceeded only once and outside of the building. For School 68 there is a correlation between outdoor and indoor concentrations, and in both cases the tolerance limit for daily exposure was largely overcome. Indoor, the concentration values decreased below the daily exposure limit $\left(150 \mu \mathrm{g} \mathrm{m}^{-3}\right)$, but lay above the level of $50 \mathrm{\mu g} \mathrm{m}^{-3}$. Conversely, $\mathrm{PM}_{10}$ concentration for school 356 in Ingeniero Jacobacci, measured outside and inside of the building (Fig. 6c), shows that the air quality inside the school was higher, and only the value of 3 July exceeded the limit of $150 \mu \mathrm{g} \mathrm{m}^{-3}$. Outside, for days 3, 4, 5 and 6 July 2011, standard $\mathrm{PM}_{10}$ concentrations exceeded the limit of $150 \mu \mathrm{g} \mathrm{m}{ }^{-3}$ for a $24 \mathrm{~h}$ exposure.

$\mathrm{PM}_{10}$ values measured between September 2011 and July 2012 are also presented in Fig. 7 for Villa La Angostura and Ingeniero Jacobacci in combination with wind and rain data. In both cities, the level of breathable aerosols was very high from September 2011 to January 2012 (high to moderate risk to health); values were above the annual limit in most of the stations, with some of them surpassing the daily limit. In Ingeniero Jacobacci, the $\mathrm{PM}_{10}$ concentrations were more than the double than in Villa La Angostura. This could be related to both the significantly finer grain size characteristic of Ingeniero Jacobacci (Bonadonna et al., 2015b), higher wind and lower rain fall (Fig. 7e, f).

\section{Crisis management}

\subsection{Towns}

Municipalities affected by ash fallout organized emergency committees including civil defence, fire fighters, police and health departments among others. The municipalities of Cordilleran localities were informed about the increased seismic activity weeks before the start of the eruption, by the SERNAGEOMIN (Geological Survey of Chile) and SEGEMAR (Geological Survey of Argentina). Consequently, in Villa La Angostura, an emergency committee was formed $72 \mathrm{~h}$ before the onset of the event including local authorities, civil defence, army personnel and civilian volunteers. Masks and $400000 \mathrm{~L}$ of drinking water were prepared. In the remaining localities (Bariloche, Villa Traful, San Martin and Junín de Los Andes), emergency committees were organized during ash fallout. Civil defence conducted various press releases to inform the population, detailing a series of recommendations on how to deal with ash fall.

When problems in the supply of electricity and water arose, responsible agencies standardized services. Bodies responsible for electricity (EPEN Neuquén and CEB-Edersa Río Negro) conducted scheduled outages, maintenance, replacements and cleaning of lines, transformers and power plants. In all localities water analyses were regularly performed and in the most affected areas replacements of pumps, filter cleaning and water harvesting were scheduled where water intakes were located in streams. Distribution of potable water, masks, food and medicine was also organized. 

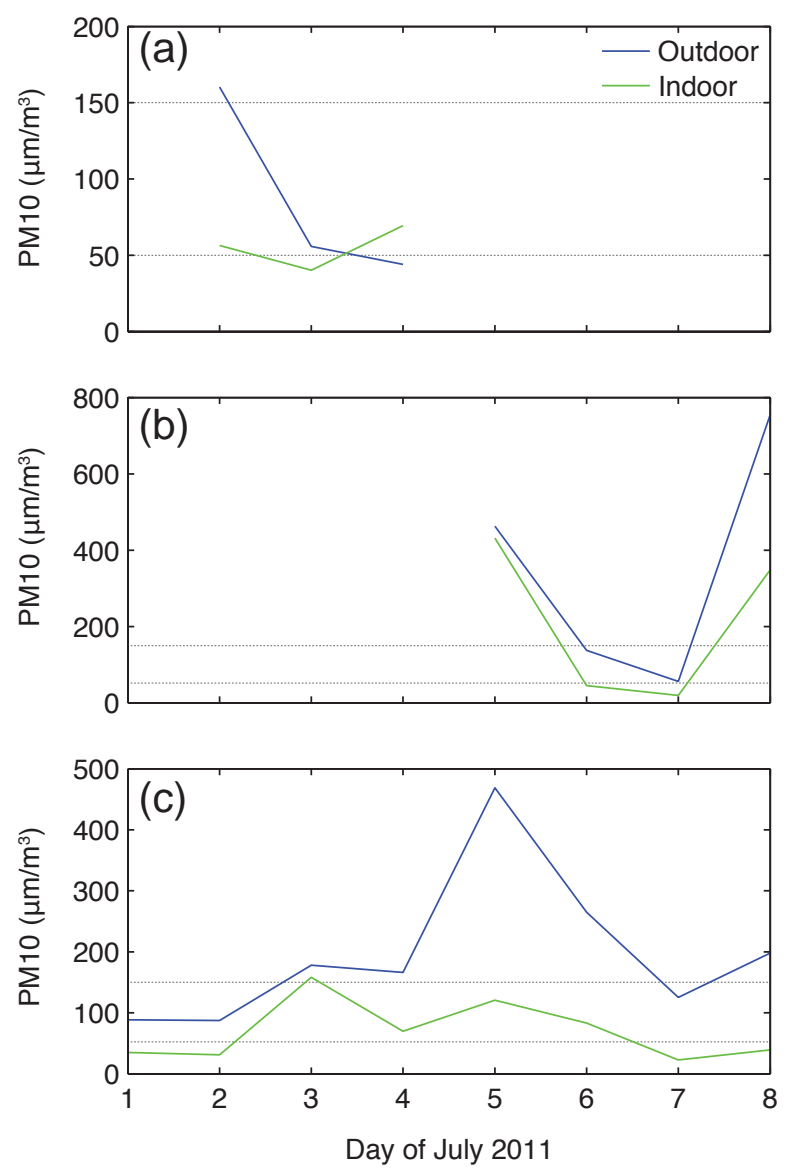

Figure 6. $\mathrm{PM}_{10}$ concentration measured indoor and outdoor for Villa La Angostura and Ingeniero Jacobacci during the beginning of July 2011. (a) Villa La Angostura hospital; (b) Villa La Angostura CPEM 68 School; (c) Ingeniero Jacobacci School 356. The horizontal lines indicate maximum levels for a $24 \mathrm{~h}$ exposure $\left(150 \mu \mathrm{g} \mathrm{m}^{-3}\right)$ and for an exposure of 1 year $\left(50 \mu \mathrm{g} \mathrm{m}^{-3}\right)$.

Volunteer groups were formed to clean roofs (Villa La Angostura), streets (Bariloche, Ingeniero Jacobacci) and seal buildings openings (Ingeniero Jacobacci). In Villa La Angostura, Bariloche and Ingeniero Jacobacci, municipalities conducted street-cleaning operations, evacuating the removed ash by private trucks to municipal quarries. Removal of ash in Villa la Angostura was managed by the emergency committee. Over a million and a half cubic metres of volcanic ash and lapilli were removed from Villa La Angostura in the 8 months between 2011 and late April 2012 (Fig. 5c) and deposited in an abandoned quarry in the Río Bonito Valley, close to Puerto Manzano. In Villa Traful, cleaning operations continued until October.

During the first week of the eruption, most municipalities declared a state of emergency. In Villa La Angostura, funds designated for other purposes were used for emergency management, including funds from government, province and/or donations. In Villa La Angostura, Villa Traful, Bar- iloche and Jacobacci, aid was sent to the isolated rural inhabitants including drinking water, livestock grazing, firewood and masks. In the remaining municipalities affected by ash fall, emergency committees were assembled for communicating recommendations to the population and for scheduling the suspension of classes and public activities.

Civil defence personnel, army, and fire management volunteers cleaned the channels in order to prevent the formation of lahars (Fig. 5d). During the first weeks of the eruption, civil defence removed trees and temporary sediment that formed in streams in the area of Villa La Angostura. Between August and November, additional cleaning tasks in these streams were performed, including the replacement of bridges to avoid potential floods caused by their obstructions. In Villa La Angostura, a group of experts formed by civil defence personnel and mountaineers performed a daily to weekly monitoring of the stability of the snowpack with interbedded ash.

\subsection{Provincial governments}

\subsubsection{Neuquén}

The government of Neuquén sent an official request to the National Parliament to declare a "state of economic and social emergency and environmental disaster". A local declaration of "disaster area and emergency" was also signed with local entrepreneurs for San Martín de los Andes, which would result in tax benefits and credit to sustain employment. The Social Security Institute of Neuquén sent two trucks with $23000 \mathrm{~L}$ of water and 13000 masks for distribution in Villa La Angostura, Villa Traful, Bariloche and San Martin de los Andes.

\subsubsection{Río Negro and Chubut}

The government of Río Negro signed the declaration of Agricultural, Economic and Tourism Disaster for localities of the "Línea Sur" and the economic and tourism declaration of emergency for the departments of Pilcaniyeu and Bariloche. Aid sent by the central government was delivered, including a contribution of ARS 1 million for the municipality of Bariloche, another ARS 500000 for Jacobacci and ARS 150000 for Pilcaniyeu, Comallo and Maquinchao. Potable water and forage were distributed. The provincial civil defence adopted preventive measures in all locations and worked with the different municipalities. The province of Chubut also declared an agricultural emergency.

\subsection{National government}

The Argentinean army was mobilized by the Ministry of Defence to assist affected people. The Ministry of Health sent bronchodilators, masks, eye drops and a new ambulance to the hospital in Bariloche. Water treatment plants and 10 silos were sent for cattle feed. The agricultural emergency was 

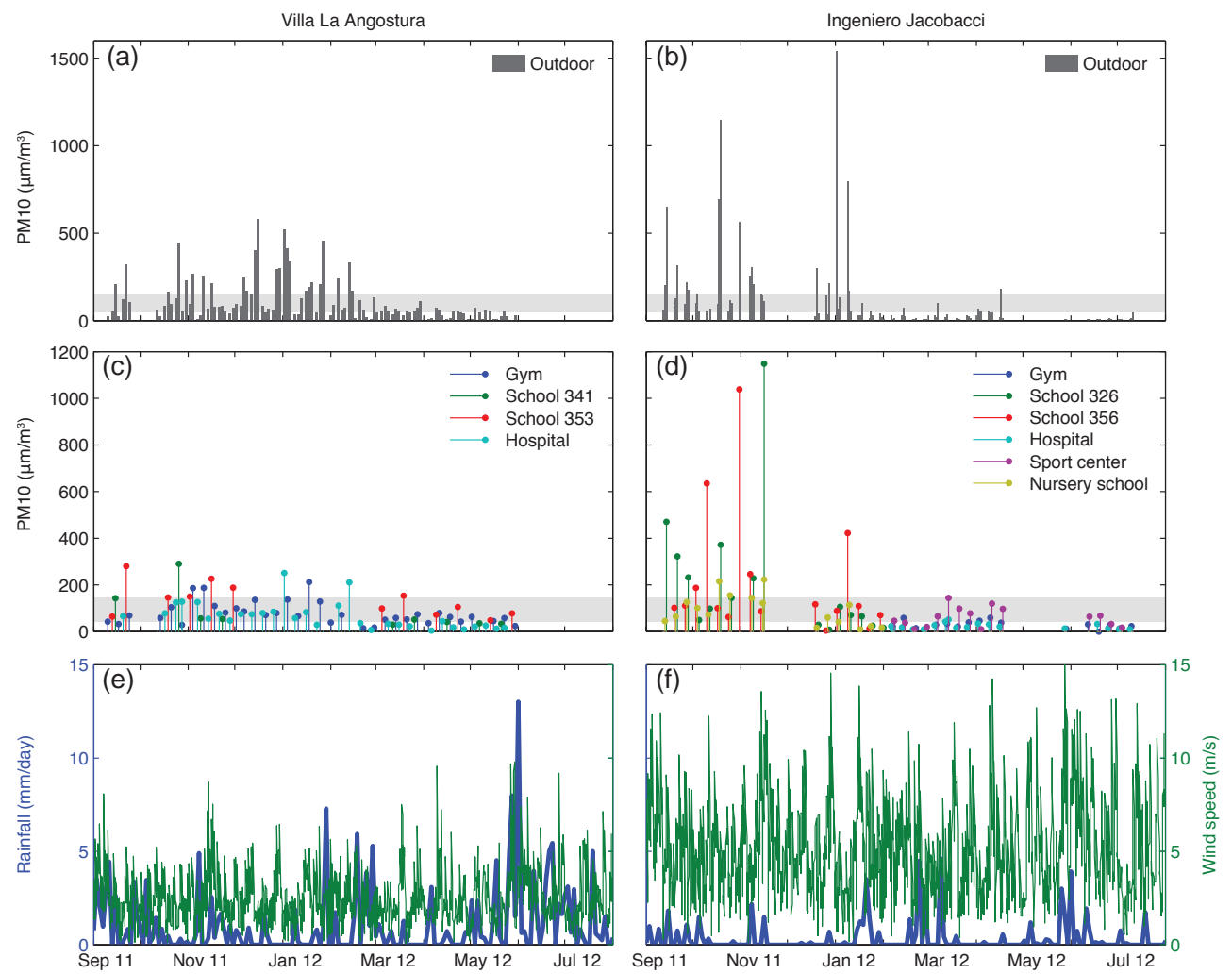

Figure 7. $\mathrm{PM}_{10}$ concentrations between September 2011 and July 2012 for (a) Villa La Angostura (outdoor station), (b) Ingeniero Jacobacci (outdoor station), (c) Villa La Angostura (indoor measurements) and (d) Ingeniero Jacobacci (indoor measurements). Shaded area indicates maximum levels for a $24 \mathrm{~h}$ exposure $\left(150 \mu \mathrm{g} \mathrm{m}^{-3}\right)$ and for an exposure of 1 year $\left(50 \mu \mathrm{g} \mathrm{m}^{-3}\right)$. Daily rainfall and wind speed averaged over $6 \mathrm{~h}$ obtained from the NOAA NCEP/NCAR Reanalysis database are also shown for (e) Villa La Angostura and (f) Ingeniero Jacobacci.

declared in Chubut, Neuquén and Río Negro. Fish farming was incorporated into the emergency declaration to assist fish farmers in the three provinces. National organizations developed different tasks during the crisis, to standardize infrastructure and services. These included civil defence, department of transportation, border police, coast guard, firefighter, police, municipalities, agencies responsible for providing electricity and water. The National Department of Transportation blocked the passenger transit on the mountain roads during the first days of the eruption.

During the course of the eruption, the National Department of Transportation, the National Gendarmerie, civil defence and police assisted the traffic. The coast guard and the national parks banned navigation in lakes due to the large amount of suspended tephra. On 4 July, the president announced a series of measures for the Patagonian area affected by the eruption, including tax benefits, salaries of ARS 1700 to support the gastronomy and hospitality sectors, commerce and industry. ARS 10 million were used to serve 1400 farmers in the area. To complete the cleaning operations, a credit of USD 7 million from IDB (Inter-American Development Bank) was used. Contributions of ARS 1 million from the national treasury were sent both to Villa la Angostura and Bar- iloche. In addition, ARS 10 million were used for the south area. INTA worked from the beginning of the eruption developing reports on current status and recommendations for the livestock in the sector of Patagonia. The International Charter (www.disasterscharter.org) was activated through the National Commission on Space Activities (CONAE) for access to satellite imagery to monitor the ash plume. The commission of Risk Analysis and Special Projects (ARPE) of the National Civil Protection agency processed information and generated reports that were transmitted to all agencies involved in the emergency response. They also reported a total loss of USD 462 million, reaching the $0.32 \%$ of the National Annual Budget (Ministerio del Interior, 2012).

On 4 July, the UN mission (United Nations Program for Environment/Office of Environmental Disaster Humanitarian Affairs Unit), managed by the National Director of Civil Protection through the Minister of Interior, reached Argentina in order to help manage the crisis related to the eruption of Cordón Caulle. The team included a coordinator and experts in geology and environmental pollution. The group consisted of the UN and national partners of the National Civil Protection and addressed SEGEMAR with missions to the affected area between 6 and 15 July 2011 (DNPC, 2011). 
SEGEMAR sent personnel to the affected area from the first week of the eruption to characterize the tephra deposit and assess the lahar hazard, to measure air quality and to participate in the crisis committee.

\section{Perspective on the occurrence of a potential new similar eruption}

In order to assess the likelihood of tephra deposition related to the $2011 \mathrm{CC}$ eruption compared to the whole possible spectrum of atmospheric pattern, we applied probabilistic methods commonly used for hazard assessment purposes. In particular, we applied the analytical model TEPHRA2 (Bonadonna et al., 2005) coupled with probabilistic approaches developed to model long-lasting eruptions (Bonadonna, 2006; Biass et al., 2014). We focus only on the most vigorous initial phase (layer A-F, 4-5 June 2011; Pistolesi et al., 2015), characterized by plume heights of 11$14 \mathrm{~km}$ a.s.1. over a duration of 24-30 h. Eruption source parameters (ESPs) were identified from Pistolesi et al. (2015) and Bonadonna et al. (2015a, b) and were varied within a certain range to account for uncertainties and intrinsic variability of the system (Table 8). Atmospheric conditions were obtained from the NOAA NCEP/NCAR Reanalysis database (Kalnay et al., 1996) for the period 2000-2015, providing four daily wind profiles. No relevant seasonal pattern was observed below $20 \mathrm{~km}$ a.s.1. (Fig. 8, Appendix B).

1000 eruptions were simulated following the long-lasting eruption range scenario of Biass et al. (2014). For each simulation, eruption dates and durations were stochastically sampled within the predefined ranges in order to retrieve the corresponding wind profiles. The median and sigma values of a Gaussian total grain-size distribution were sampled (Table 8), and aggregation is accounted for using the method of Bonadonna et al. (2002) (see Biass et al., 2014 for more details). The entire eruption duration was split into $6 \mathrm{~h}$ long intervals, for which a plume height was sampled and converted into an erupted mass using the formulation of mass eruption rate of Degruyter and Bonadonna (2012). ESPs were assumed constant over $6 \mathrm{~h}$ long periods, and each $6 \mathrm{~h}$ period was sent separately to the TEPHRA 2 model. The final accumulation consists of the sum of these separate periods.

Results are presented in various forms (Fig. 8). First, we compiled maps contouring the probability of exceeding a given tephra accumulation. Figure 8a shows the geographical distribution of probabilities to exceed an accumulation of $10 \mathrm{~kg} \mathrm{~m}^{-2}$, which indicates damage to vegetation (hazard map for 1 and $100 \mathrm{~kg} \mathrm{~m}^{-2}$ are shown in Appendix B for disruption of airport operation and collapse of the weakest roofs, respectively). Second, exceeding probabilities of tephra accumulation are also shown as hazard curves for selected towns (Anticura and Riñinahue in Chile and San Martin de Los Andes, Villa Traful, Villa La Angostura and Bariloche in Argentina; Fig. 8b). Probabilities $>60 \%$ of reach-
Table 8. Eruption source parameters used for the modeling with TEPHRA2 as derived from observations and inversions of field data (Pistolesi et al., 2015; Bonadonna et al., 2015a, b).

\begin{tabular}{lcc}
\hline Eruption source parameter & Minimum & Maximum \\
\hline Plume height $(\mathrm{km}$ a.s.l.) & 10 & 14 \\
Erupted mass $\left(\times 10^{11} \mathrm{~kg}\right)$ & 3.5 & 5.5 \\
Duration $(\mathrm{h})$ & 24 & 30 \\
Median TGSD $(\Phi)$ & -3 & -1 \\
Sigma TGSD $(\Phi)$ & 2 & 3 \\
Aggregation coefficient $(\%)$ & 30 & 70 \\
\hline TEPHRA2 parameters & Value & \\
\hline Plume model & Beta \\
$\alpha$ & 3 & \\
$\beta$ & 1.8 \\
Fall time threshold $(\mathrm{s})$ & 30500 \\
Diffusion coefficient $\left(\mathrm{m}^{2} \mathrm{~s}^{-1}\right)$ & 3900 \\
\hline
\end{tabular}

ing $10 \mathrm{~kg} \mathrm{~m}^{-2}$ are shown only for the Chilean area and are $<60 \%$ for the Argentinean area (Fig. 8a, b). Only the towns of Anticura (Chile) and Villa La Angostura (Argentina) reach accumulations $>100 \mathrm{~kg} \mathrm{~m}^{-2}$, while the lowest accumulations are shown by San Martin de Los Andes and Bariloche $\left(<20 \mathrm{~kg} \mathrm{~m}^{-2}\right.$; Fig. 8 b). Third, probability maps were converted into probabilistic isomass maps, which show the typical tephra accumulation given a probability of occurrence of the hazard (e.g. Biass et al., 2013). Figure 8c shows the probability of occurrence of $1,10,50$ and $90 \%$ for the tephra accumulation of $100 \mathrm{~kg} \mathrm{~m}^{-2}$ compared to the accumulation of $100 \mathrm{~kg} \mathrm{~m}^{-2}$ observed for the climactic phase of the eruption (4-5 June), suggesting that this phase is within $1 \%$ of all the possible atmospheric conditions recorded in the last 15 years. In addition, the most common wind direction is towards east, i.e. median values of $90^{\circ}$ from the north, with no significant seasonality patterns (Fig. 8d). The dispersion that characterized the whole month of June 2011 was anomalous with respect to the general trend as it swept from SE to NE with only a few days being dispersed directly E (i.e. $20 \%$ of the time: 11, 14, 15, 23, 28 June; Table 2).

\section{Discussion}

The orientation of the southern Andes volcanic arc, the persistence of westerly winds and the location of human settlements on both sides of the Andean Cordillera, imply a largely different impact of explosive eruptions on Chilean and $\mathrm{Ar}$ gentinean settlements. In general, Chilean settlements are exposed to proximal phenomena (coarse tephra fallout, PDCs, lava flows, lahars), while Argentinean settlements are often affected by significant lapilli and ash fallout dispersed over very large areas. 

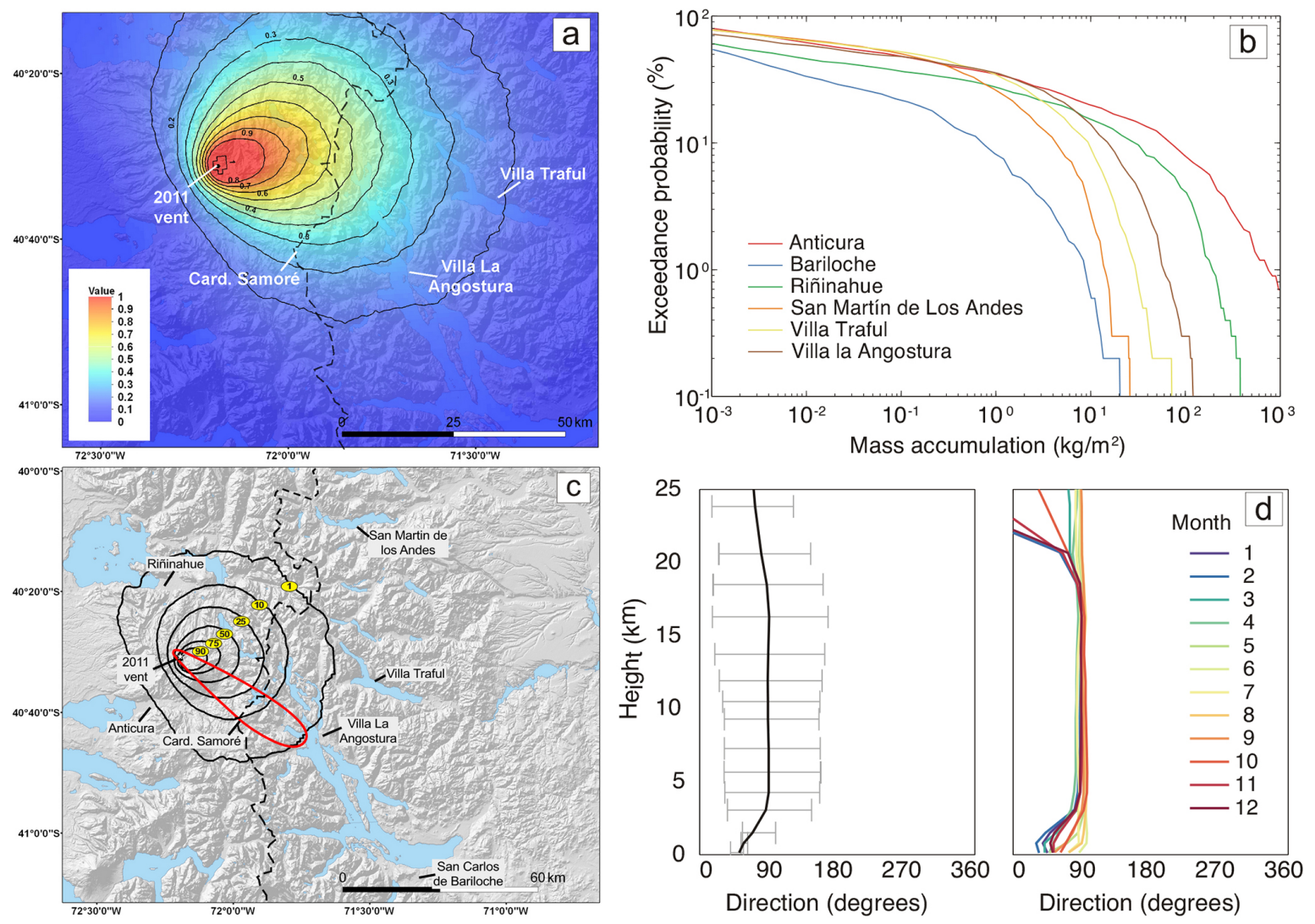

Figure 8. (a) Spatial distribution of the probability of reaching a tephra accumulation of $10 \mathrm{~kg} \mathrm{~m}^{-2}$; (b) hazard curves showing the exceeding probability for the towns of Anticura and Riñinahue in Chile and San Martin de Los Andes, Villa Traful, Villa La Angostura and Bariloche in Argentina; (c) location of the $100 \mathrm{~kg} \mathrm{~m}^{-2}$ isomass contours as inferred from the probabilistic modelling for probabilities of occurrence of $1,10,50$ and $90 \%$ resulting from an eruption of similar intensity of the $2011 \mathrm{CC}$ climactic phase (see also Table 8); the red isoline shows the $100 \mathrm{~kg} \mathrm{~m}^{-2}$ isomass line for the $2011 \mathrm{CC}$ climactic phase as compiled by Bonadonna et al. (2015a) as a comparison; (d) statistical analysis of the wind direction based on the NOAA NCEP/NCAR Reanalysis database for the period 2000-2015 (left plots shows the median value and standard deviation, while the right plot shows the median value for each month; see main text for more details).

The 2011 CC eruption produced multiple types of impact in different areas as discussed in the previous sections. Table 9 summarizes the principal types of recorded impact, the affected areas, beginning and duration of impact, deposit thickness and mean grain size. The map in Fig. 9 shows the distribution of the different impact types associated with each locality. In this paper, the different types of impacts were identified and described in a qualitative way. As there is no quantification of the impact, the parameters used for comparing the impact at different areas is the number of different impacts recorded. From these data, it can be observed that the localities with a thickness of tephra higher than $2 \mathrm{~cm}$ suffered a larger variety of impacts than those with less than $2 \mathrm{~cm}$ of tephra thickness (Fig. 9a). These areas experienced disruption to transport systems (aviation, ground transportation, navigation), cut-offs of electric and water supply, suspension of activities in urban areas, health problems, agricultural and livestock disruptions, vegetation damage, animal death, floods and lahars. The impact not only varied accord- ing to the thickness (and distance from vent), but also according to the amount of population and degree of development of urbanization. For instance, Bariloche, with a relatively small tephra thickness compared to Villa La Angostura (Table 6), recorded a variety of impact typologies (Table 7) due to the higher population density and urbanization. In medial areas, with a deposit thickness of 3-1 cm along the plume axis, several types of impact were experienced, including roads closure, cuts of electric and water supply, suspension of activities in urban areas, health problems, agricultural and livestock disruptions, vegetation damage and animal death. In distal areas ( $1 \mathrm{~cm}$ or less of tephra), the impact included agricultural and livestock disruptions, interruption of transport systems (closure of airports and roads) and suspension of activities during days of tephra fall or re-suspension. It is important to note that the thickness reported in the media was higher than the measured thickness, except for Paso Samoré section, where the measured thickness was higher (Table 7). 


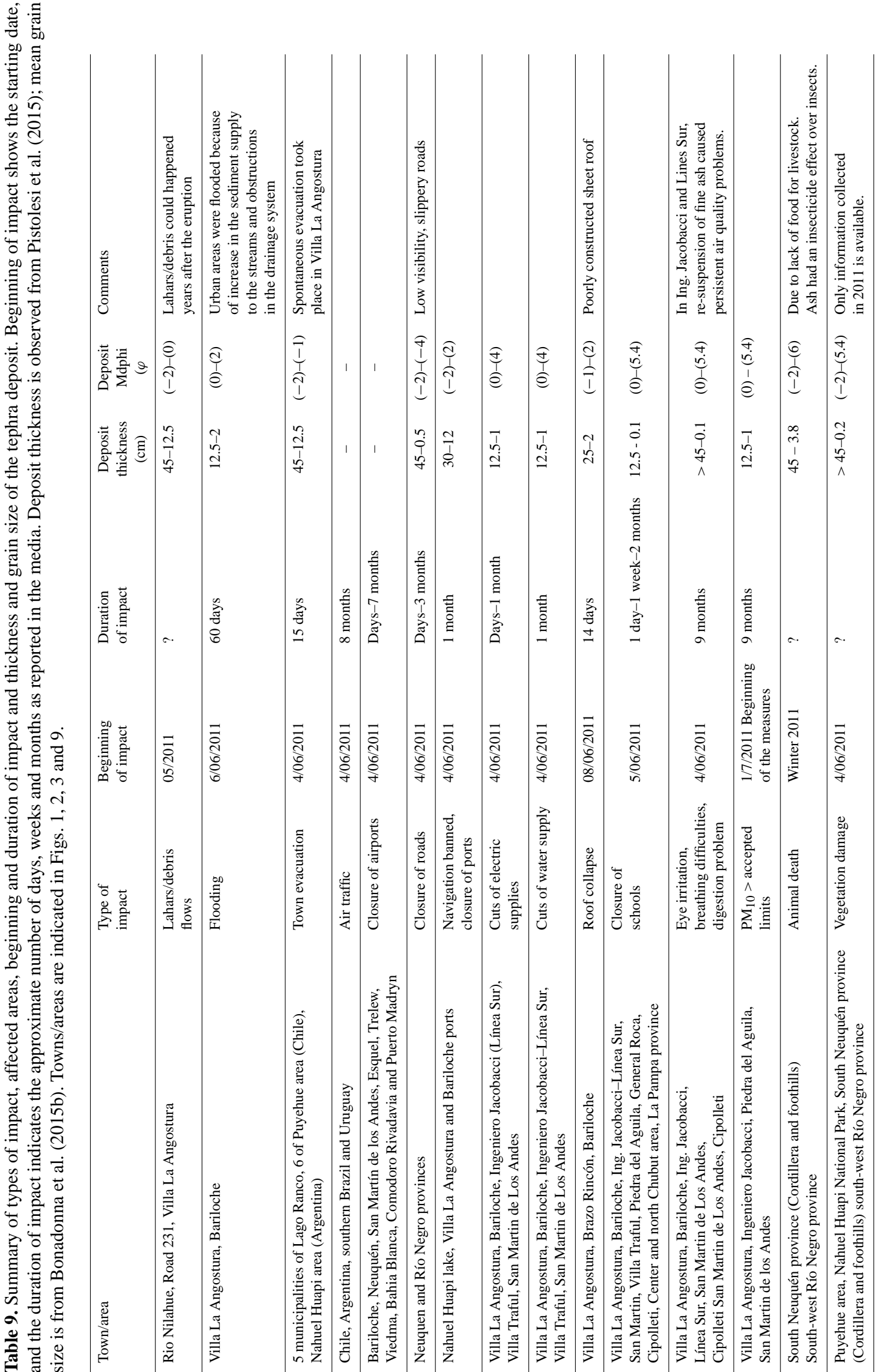



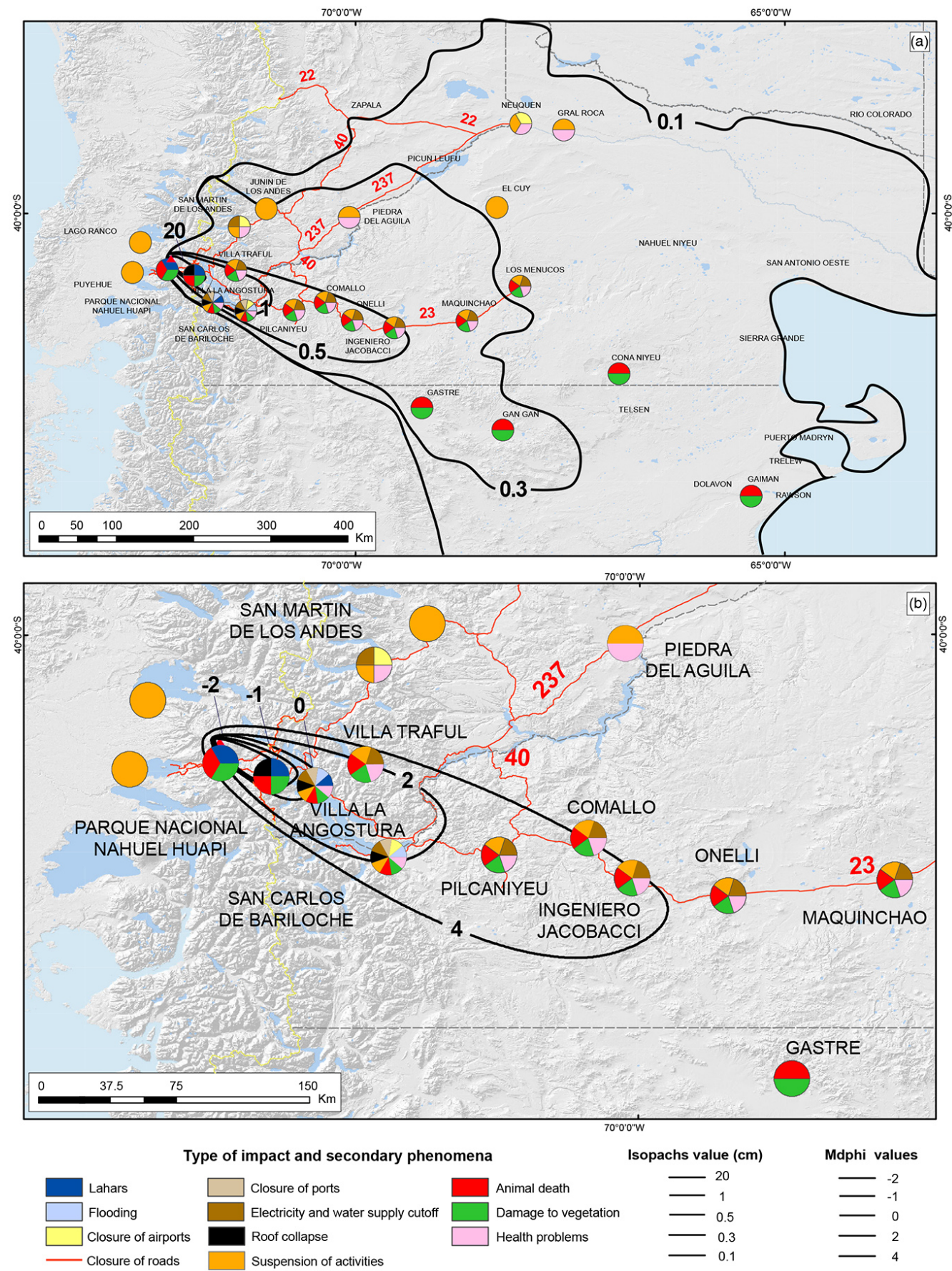

Figure 9. Distribution of the different impact types and secondary phenomena (indicated in the pie charts) associated with various localities in Argentina (southeast Río Negro, South Neuquén and north of Chubut provinces) and Chile (Lago Ranco and Puyehue areas). (a) Isopach lines of unit I are shown as solid lines from 20 to $0.5 \mathrm{~cm}$ (Pistolesi et al., 2015); isolines of 0.3 and $0.1 \mathrm{~cm}$ are associated with the whole deposit observed by Gáitan et al. (2011). (b) Solid lines represent the median diameter (Mdphi) for unit I (Bonadonna et al., 2015b).

Besides the thickness, grain-size is also a very important factor affecting the type of impact. Figure $9 \mathrm{~b}$ shows the impact map with the median diameter (Mdphi, with phi $=$ $-\log _{2} D$, where $D$ is the particle diameter in millimeters) for unit I (Bonadonna et al., 2015b) and the Table 9 summa- rizes the Mdphi interval for each impact. The large amount of dispersed tephra also extended the impact to distal areas. In areas with Mdphi values higher than 2 the impact consisted of a large variety of problems related with fine ash re-suspension (including road closure due to low visibility, 
cuts of electric and water supply, suspension of activities in urban areas, health problems, agricultural and livestock disruptions, air traffic disruption and closure of airports). Additional problems related to the coarser grain size of the fallout material were recognized in areas with Mdphi values lower than 2: ground transportation, navigation due to sedimentation of lapilli on the lakes, roof collapse, vegetation damage, animal death, floods and lahars. The fine ash $\left(\mathrm{PM}_{10}\right)$ concentration measured during eruption in Ingeniero Jacobacci and Villa La Angostura is consistent with the Mdphi values estimated (Fig. 7). $\mathrm{PM}_{10}$ values at Ingeniero Jacobacci (Mdphi 5.42) were more than twice than in Villa La Angostura (Mdphi 0.22).

Impact at proximal sites was possibly increased by the emplacement of the fine ash deposits related to the final, lower intensity phases of the eruption. For example, the occurrence of fine ash on top of the sequence was responsible for the high efficient rainfall runoff and downstream sedimentation producing floods and lahar events in Villa la Angostura and along the national road 231 between the Argentine-Chilean pass and Villa La Angostura. This effect has been largely described for several mid- to low-intensity eruptions also at Vesuvius, Italy (Cioni et al., 2008).

As a direct consequence of the 2011 Cordón Caulle eruption, the Argentinean government has made several attempts to improve the management of the volcanic risk, and new funds have been allowed for volcano monitoring at National and Provincial levels since 2011-2012. In addition, a Risk Management Commission was created by the National Ministry of Science and Technology in order to organize the institutions involved with prevention and response. This commission is preparing protocols to manage different types of risk. Finally, interesting data and similarities emerge from the analysis of available information on impact related to other three large-scale, well-documented eruptions occurred in the last 100 years in the southern Andes: Quizapu (Kittl, 1933; Hildreth and Drake, 1992), Hudson (Naranjo et al., 1993; Scasso et al., 1994), Chaitén (Lara, 2009; Alfano et al., 2011; Major and Lara, 2013). It is interesting to note that the regions downwind or very close to the different erupting volcanoes suffered very similar impacts (e.g. health problems, damage to vegetation, death of animals, roof collapse, air traffic disruptions, roads closure, lahars and flooding), suggesting that a detailed collection of all the data on impact immediately after an eruption can help the development of contingency plans.

\subsection{The 1932 Quizapu eruption}

The Quizapu eruption of 10 April 1932 is the largest Andean eruption of the XX Century (tephra volume of $4 \mathrm{~km}^{3}$ Dense Rock Equivalent, DRE; Hildreth and Drake, 1992). Although the eruption generated no casualties or injuries, it had a large economic impact even for the less developed societal and economic organization of the time. Similarly to CC, in proximal areas (Chile) lahars were reported; a dam break also generated damage downstream Río Maule (Hildreth and Drake, 1992). In Argentina, tephra fallout strongly affected the economy of the southern portion of Mendoza, La Pampa and Buenos Aires provinces, mainly based on subsistence horticultural farming, as a consequence of burial of cultivated and grass lands, and impact in urban areas (Mikkan, 2012). The impact of the eruption included a high mortality of farm animals, due to grass and water scarcity related to increased stream water turbidity. As a long-term effect, Abraham and Prieto (1993) remarked the intense desertification of south Mendoza as a consequence of the eruption.

\subsection{The 1991 Hudson eruption}

The eruption of Hudson volcano in August 1991 is considered the second largest eruption in magnitude in the 20th century for the southern Andes. With a total volume of $2.7 \mathrm{~km}^{3}$ (DRE), the eruption covered with tephra a great surface of Santa Cruz and Chubut provinces (Argentina), and fallout was reported as far as $1000 \mathrm{~km}$ in Malvinas (Falkland Is.) (Naranjo et al., 1993; Scasso et al., 1994). The impact of this eruption, very similar to that described for the CC eruption, included big economic losses in Patagonia, mainly from the impact on livestock and crops, air traffic disruption and water contamination. As in CC, Wilson et al. $(2010,2012)$ also reported interruptions and disruptions in electricity and water supply, accumulation of pumice in lakes over a long period of time, abrasion and weathering of machinery and electrical devices. An important psychological-social impact in the population was also recorded, combined with the abandonment from farms and towns (in Puerto Ibañez, Chile, the spontaneous evacuation of people was gradual, reporting a decrease of $30 \%$ from a starting population of 4000).

Desertification of the extra Andean Patagonia was an important long-term effect of the eruption that needs to be considered for a comprehensive long-term land-use planning. The eruption affected different types of farms, including pastoral farms with sheep and cattle and horticultural farms (Wilson et al., 2010, 2012). Similarly to the CC eruption, a massive loss of sheep (1 million) and cattle (about a thousand) in Argentina and Chile was estimated, due to burial of vegetation from tephra, water contamination and animal poor health conditions. As in the case of CC eruption, Wilson et al. $(2010,2012)$ also reported animals with gastrointestinal affections, teeth abrasion, blindness, immobilization and dehydration. Impact on vegetation varied according to the thickness of the tephra deposit. It has been reported that 2-5 years after the eruption vegetation recovered in the Cordillera and in the steppe. In some cases, mostly in horticultural farms, activity was strongly affected by remobilized ash, and recovery was accelerated after the tephra was mixed with the soils (Wilson et al., 2010, 2012). In the Chilean Cordillera, where the tephra is the thickest, vegetation recovery was slower in spite of the high humidity. Pas- 
tures were completely lost where tephra thickness was more than $10 \mathrm{~cm}$. Finally, a strong effect on post-eruptive resilience of the impacted territories was also related to the remobilization of ash, which started generating ash storms that extended the problems related to the syn-eruptive phase for several months.

\subsection{The 2008 Chaitén eruption}

The eruption of Chaitén volcano began in May 2008 and represents the most similar case to the $\mathrm{CC}$ eruption, in terms of magma composition and eruption intensity, magnitude and duration. Also in this case, however, the general problems related to the eruption were still not very different from those described for the largest eruptions of Quizapu and Hudson. Tephra was dispersed eastward from the volcano, affecting a wide area of Argentina with an estimated tephra volume of about $1 \mathrm{~km}^{3}$ (Alfano et al., 2011). Chaitén town (4600 inhabitants, $10 \mathrm{~km}$ south of the volcano) was evacuated immediately before the eruption (Lara, 2009; Major and Lara, 2013). Tephra dispersal affected commercial airline traffic and disrupted activities in downwind communities. Also flooding, sediment transport and erosion affected Chaitén, disrupting aquaculture and tourism, among other activities.

In proximal areas, PDCs, tephra fallout and lahars heavily damaged approximately $480 \mathrm{~km}^{2}$ of forest (Swanson el al., 2013). Within days of the heaviest tephra fallout, small rainstorms produced an extraordinary sedimentation response in the Chaitén river basin, with an initial lahar followed closely by two surges of muddy floodwater. One of the main factors contributing to the high runoff capacity and the rapid downstream sedimentation appears to be the thick impermeable fine ash cover mantling the whole basin and the steepness of the basin slopes (Pierson et al., 2013). Lahars and floods in the Chaitén river basin cut roads, and the coastal town of Chaitén was inundated by 1-3 $\mathrm{m}$ of volcanic sediment (Lara, 2009). Tephra fallout caused burying of the airport runaway and interruption of ferries activity. A complex tephra sequence was deposited over a broad area both in Argentina and Chile (Alfano et al., 2011), affecting infrastructures, agriculture and population: electricity networks suffered damage from tephra deposition and from fallen trees; water supply was affected by increased turbidity; ground transportation was affected by reduced visibility. Tephra fallout in distal areas strongly impacted agricultural lands, causing a shortage of water and forage for the animals. Release of volatile elements to the environment resulted in ephemeral compositional changes in biogeochemistry of soil biota and lakes. Fine ash remobilization by wind impacted the regional road traffic for a long time (Martin et al., 2009). Chaitén tephra contains abundant ash in the respirable fraction and the concentration in the air exceeded the WHO limits. Cristobalite nanofibers with possible adverse effects were also found in the deposit (Martin et al., 2009).

\section{Summary remarks}

All the information on the impact of the CC 2011 eruption, the statistical assessment of the conditional probability of occurrence of a similar event, and the direct comparison with other recent well-studied events in the southern Andes can be used as a proxy for assessing the expected impact of future eruptions in the region.

1. Impact on population: the highest impact on population associated with the $\mathrm{CC}$ eruption occurred during the first month (4-30 June 2011). However, remobilization of pyroclastic deposits by water and wind caused an impact to exposed population also during the following months (until January 2012). Lahars were also generated in the mid-proximal area, characterized by high relief and abundant availability of water. In the "Patagonia extra-andina" (lowland area), with a semi-arid climate, the tephra deposits were reworked by strong winds, producing "ash storms" even months after the eruption onset. Similar effects are described for Hudson and Chaitén eruptions.

2. Crisis management and evacuation: in Chile, ONEMI ordered the evacuation of 710 people on 4 June. The number of evacuated people reached 4270 during the first days of the eruption and the evacuation lasted 16 days. In Argentina 27 families close to the Nahuel Huapi Lake received the evacuation order and a total of 4000 people from Villa La Angostura area evacuated spontaneously. Since the beginning of the eruption emergency committees were assembled for communicating recommendation to the population.

3. Impact on transport: during the first month of the eruption a large number of flights were cancelled and many airports had to close. Additional flight cancellations occurred in July, October and November 2011 and in January 2012; Bariloche airport closed for 7 months. At the same time, roads were also affected by tephra fallout: the international Pass Cardenal Samore $(45-15 \mathrm{~cm}$ ash fall) closed for 3 months. In June 2011, National and Provincial roads in the province of Rio Negro and Neuquén were closed either at night or during the day due to low visibility combined with slippery surfaces (tephra thickness of $15-0.5 \mathrm{~cm}$ ). Due to the accumulation of tephra (thickness between 12 and $30 \mathrm{~cm}$ ) on Lake Nahuel Huapi and on its various branches, Naval Prefecture banned the navigation and closed lake ports during June 2011.

4. Impact on the urban system: between 35 and $100 \mathrm{~km} \mathrm{SE}$ from the volcano several poorly constructed roofs collapsed due to tephra accumulation. Obstruction of urban drainage system occurred during rainy days because the water solidified the tephra deposit on the streets. Power 
cuts were recorded since the beginning of the eruption and were common during the first weeks. Tephra fallout affected the water supply; water contamination was mostly due to an increase in turbidity in areas where intakes are in open streams. The tephra also clogged water pumps and filters. School and administrative activities were suspended in several towns. Rainfall during the volcanic eruption can have both a positive and negative effect on impact: on one hand it can cause electric shortage, water clogging, flooding and lahar, but on anther hand it helps to reduce ash re-suspension and lower $\mathrm{PM}_{10}$ values.

5. Impact on health: even though there are not official data on health, the hospitals reported an increase of medical visits for respiratory issues, eye problems and stress. A SEGEMAR team for the control of air quality performed measurements of $\mathrm{PM}_{10}$ in Villa La Angostura and Ingeniero Jacobacci between September 2011 and July 2012. In both cities, the level of breathable aerosols from September 2011 to January 2012 was above the annual limit $\left(50 \mu \mathrm{g} \mathrm{m}^{-3}\right)$ in most of the stations (high to moderate risk to health), with some of them surpassing also the daily limit $\left(150 \mu \mathrm{g} \mathrm{m}^{-3}\right)$.

6. Impact on animals: tephra covered agricultural lands (grass and water pools), causing a shortage of water and forage for the animals. The CC 2011 eruption intensified the crisis that had been affecting the livestock sector since 2007 due to persistent drought. This resulted in loss of animals, low birth rates and high predation. The tephra impact on fish populations was variable; the microorganisms were the most affected among the aquatic biota. Native fish populations were mostly affected in terms of displacement of young members from the most affected coastal areas to the open waters with lower concentration of tephra but less protected. The insecticidal effect of the Cordón Caulle tephra removed much of herbivorous insects and affected both the bee and wasp populations.

7. Impact on vegetation: the eruption occurred at the beginning of the winter when most plants had very low metabolic activity, but the germination of some species for the following spring was compromised depending on the accumulation of tephra and its distribution. In the Cordillera area, thick deposits of fine tephra in forest canopy caused breakage on large trees and bowing on small trees, even if the exotic trees like pines were the most impacted. In the "Patagonia extra-andina", observations made between September and October 2011 confirmed a delay in growth, mainly in wet meadows and steppes, expressed in lower forage biomass per unit area. In the steppe, the recovery of wet meadows appeared to be associated with the level of precipitation.
8. Probabilistic analysis of atmospheric and eruptive conditions have shown that the main direction of dispersal is directly towards east of the volcano and that the tephra accumulation associated with the climactic phase of the CC 2011 eruption has about $1 \%$ probability of occurrence. San Martin de Los Andes and Bariloche share similar probabilities of tephra accumulation, even though Bariloche was more affected during the $2011 \mathrm{CC}$ eruption. However, considering the high density of active volcanoes between Chile and Argentina (i.e. 112 volcanoes erupted in the Holocene), a large number of communities distributed along the border have a high potential to be affected in a similar manner regardless of the prevailing wind direction.

9. The comparison with the impact of the most recent volcanic crises in the southern Andes (i.e. Quizapu 1932, Hudson 1991 and Chaitén 2008) suggests that similar problems are related to eruptions with similar dynamics although with variable magnitude and geographic region. This is possibly mainly due to the similar economic and social development of the central-southern areas of Argentina, where wide portions of the territory are dedicated to tourism, pasture and farming, and human settlements are sparse and of medium size. This suggests that a detailed collection of data on impact immediately following the eruption can represent a useful tool to increase preparedness and to compile emergency management plans for future eruptions in the Andean region. 
Appendix A: Additional references used to describe eruption chronology and impact

Appendix A summarizes the non-academic sources (i.e. news papers and technical reports) used to describe the chronology and the impact of the $2011 \mathrm{CC}$ eruption in combination with the academic sources that are mentioned in the main text and reported in the reference list. The sources indicated with "**" are not quoted in the text.

\section{A1 Section 3: Chronology}

*Diario Andino Digital Villa La Angostura (2014)

*Diario de Río Negro (2014)

*Diario La Angostura Digital (2014)

*Diario La Mañana del Neuquén (2014)

* Diario La Nación (2014)

*Diario Página 12 (2014)

SERNAGEOMIN-OVDAS (2010 to 2012)

A2 Sections 4, 5, 6, 7 and 8: Evacuation, impact on transport systems, tourism, impact on communities, impact on infrastructures and lifelines

Abumohor et al. (2011)

Barbier (2012)

*Diario Andino Digital Villa La Angostura (2014)

*Diario de Río Negro (2014)

*Diario La Angostura Digital (2014)

*Diario La Mañana del Neuquén (2014)

*Diario La Nación (2014)

*Diario Página 12 (2014)

\section{A3 Section 9: Impact on animals}

Anselmi et al. (2012)

Corley et al. (2012)

Giraudo and Villagra (2011)

Huerta (2011)

INIBIOMA, CONICET - Comahue (2012)

INTA-EEA Chubut (2011)

INTA-EEA (2011)

Méndez Guerrero (2011)

Robles (2011)

\section{A4 Section 10: Impact on vegetation}

Gaitán et al. (2011)

Siffredi et al. (2011)

Úbeda et al. (2011)

\section{A5 Section 11: Impact on health}

* Diario Andino Digital Villa La Angostura (2014)

*Diario de Río Negro (2014)

*Diario La Angostura Digital (2014)

*Diario La Mañana del Neuquén (2014)

* Diario La Nación (2014)

* Diario Página 12 (2014)

Wilson et al. (2013)

\section{A6 Section 12: Crisis management}

*Diario Andino Digital Villa La Angostura (2014)

*Diario de Río Negro (2014)

* Diario La Angostura Digital (2014)

*Diario La Mañana del Neuquén (2014)

*Diario La Nación (2014)

*Diario Página 12 (2014)

DNPC (2011)

Ministerio del Interior (2012) 


\section{Appendix B: Hazard maps and wind analysis}
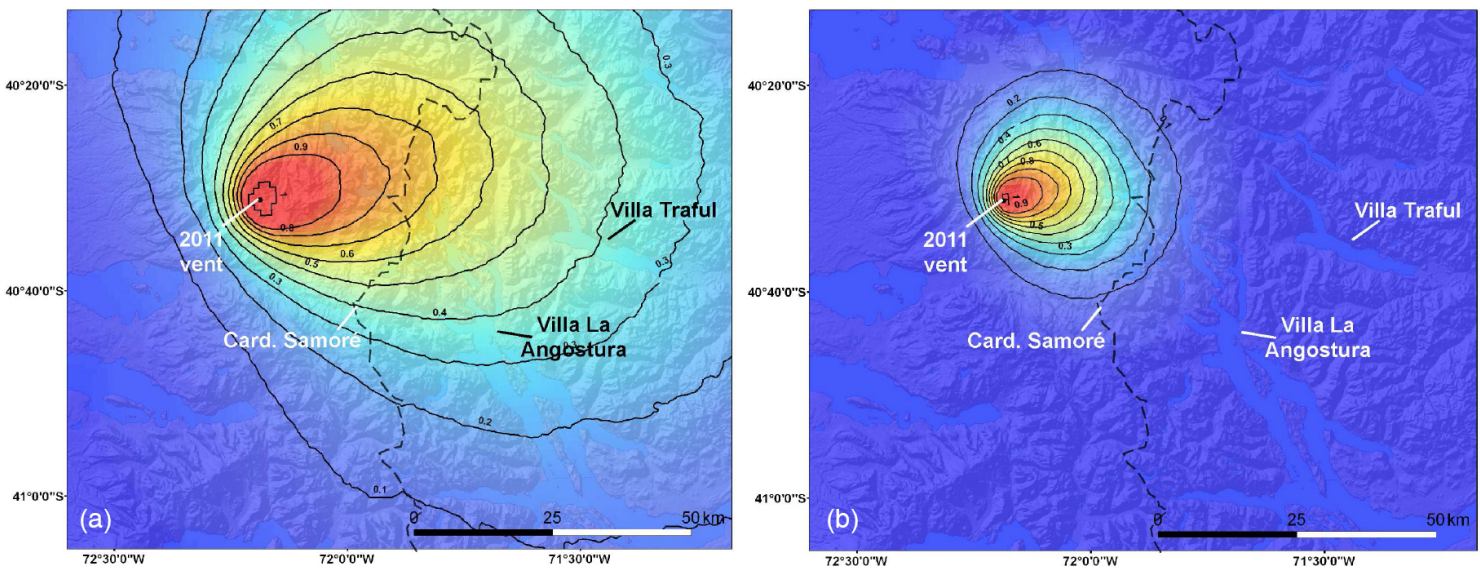

Figure B1. Hazard maps showing the spatial distribution of the probability of reaching a tephra accumulation of (a) 1 and (b) $100 \mathrm{~kg} \mathrm{~m}^{-2}$ (see also Fig. 8 of main text).
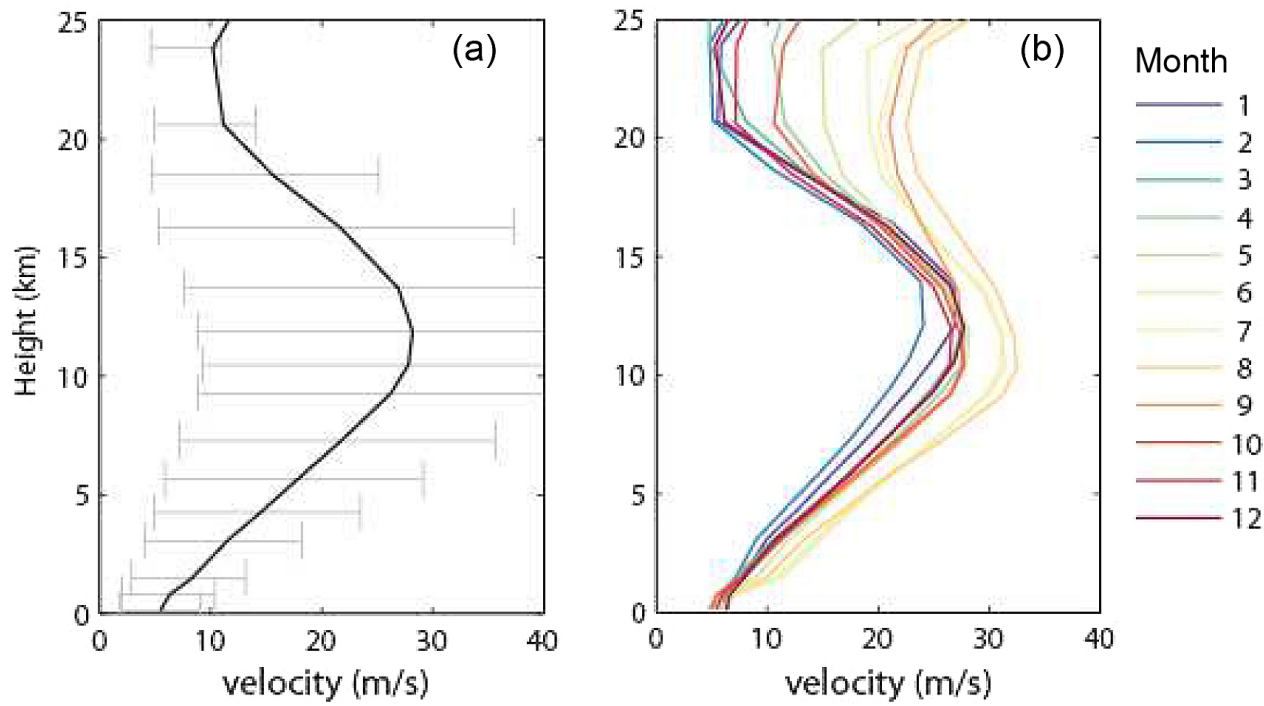

Figure B2. Statistical analysis of the wind velocity based on the NOAA NCEP/NCAR Reanalysis database for the period 2000-2015: (a) median value and standard deviation and (b) median value for each month; see Fig. 8 of main text for analysis of wind direction). 
Acknowledgements. C. Bonadonna and S. Biass were supported by Swiss National Science Foundation (SNSF; No. 200021_129997). M. Pistolesi, R. Cioni and A. Bertagnini were supported by an Italian Ministero Università e Ricerca funds (PRIN 2008 - AshErupt project). The authors are grateful to the Comité de Emergencias (COE) de Villa La Angostura and to Emiliano Respighi of the Protección Civil Argentina for sharing and discussing critical information and data. We also thank Diego Meier for his logistic assistance and constructive discussion in the field. Computations were performed on the Baobab cluster at the University of Geneva.

Edited by: G. Macedonio

Reviewed by: two anonymous referees

\section{References}

Abraham, E. and Prieto, M.: Vulcanismo y Procesos de desertificación en el Sur de Mendoza, la erupción de Quizapú en 1932 y sus efectos ambientales, in: Primeras Jornadas Nacionales de Vulcanismo, Medio Ambiente y Defensa Civil, Actas, Malargüe, Mendoza, March 1992, 45-53, 1993.

Abumohor, J. A. and Díaz, C. E.: Informe técnico consolidado, Actividad volcánica Complejo Puyehue-Cordón Caulle desde Junio a Octubre 2011, Sección de Análisis y estudios, ONEMI, Santiago, Chile, 50 pp., 2011.

Alfano, F., Bonadonna, C., Volentik, A. C. M., Connor, C. B., Watt, S. F. L., Pyle, D. M., and Connor, L. J.: Tephra stratigraphy and eruptive volume of the May, 2008, Chaitén eruption, Chile, B. Volcanol., 73, 613-630, 2011.

Anselmi, F., Valot, N., and Spinelli, G.: Diagnóstico y Propuestas de diversificación productiva departamento Los Lagos, CLER (Comité Local de Emergencia Rural, Departamento Los Lagos), 33 pp., 2012.

Barbier, J. L.: Erupción del Volcán Puyehue-Cordón Caulle en la República de Chile, 4 de junio del 2011, in: Seminario Regional "Alianzas entre el sector público y privado para la gestión del riesgo de desastres: Continuidad de gobierno y continuidad de operaciones ante situaciones de desastres", Lima, Perú, 7-8 June 2012, SP/SR-CGCORRD/Di No. 7-12, 2012.

Bertin, D., Amigo, A., Lara, L. E., Orozco, G., and Silva Parejas, C.: Erupción del Cordón Caulle 2011-2012: Evolución fase efusiva, XIII Congreso Geológico Chileno, Antofagasta, 539-541, 2012.

Biass, S., Frischknecht, C., and Bonadonna, C.: A fast GIS-based risk assessment for tephra fallout: the example of Cotopaxi volcano, Ecuador - Part II: vulnerability and risk assessment, Nat. Hazards, 65, 497-521, 2013.

Biass, S., Scaini, C., Bonadonna, C., Folch, A., Smith, K., and Höskuldsson, A.: A multi-scale risk assessment for tephra fallout and airborne concentration from multiple Icelandic volcanoes - Part 1: Hazard assessment, Nat. Hazards Earth Syst. Sci., 14, 2265-2287, doi:10.5194/nhess-14-2265-2014, 2014.

Blong, R.: Volcanic Hazards: A Sourcebook on the Effects of Eruptions, Academic Press, Australia, 424 pp. 1984.

Blong, R.: Building damage in Rabaul, Papua New Guinea, 1994, B. Volcanol., 65, 43-54, 2003.

Bonadonna, C.: Probabilistic modelling of tephra dispersion, in: Statistics in Volcanology, Special Publication of IAVCEI, edited by: Mader, H. M., Coles, S. G., Connor, C. B., and Connor, L. J., Geol. Soc. London, London, 243-259, 2006.

Bonadonna, C., Macedonio, G., and Sparks, R. S. J.: Numerical modelling of tephra fallout associated with dome collapses and Vulcanian explosions: application to hazard assessment on Montserrat, in: The Eruption of Soufrière Hills Volcano, Montserrat, from 1995 to 1999, edited by: Druitt, T. and Kokelaar, B., Geological Society of London, London, Memoirs, 21, 483-516, 2002.

Bonadonna, C., Connor, C. B., Houghton, B. F., Connor, L., Byrne, M., Laing, A., and Hincks, T. K.: Probabilistic modeling of tephra dispersal: hazard assessment of a multiphase rhyolitic eruption at Tarawera, New Zealand, J. Geophys. Res., 110, B03203, doi:10.1029/2003JB002896, 2005.

Bonadonna, C., Pistolesi, M., Cioni, R., Degruyter, W., Elissondo, M., and Baumann, V.: Dynamics of wind-affected volcanic plumes: the example of the 2011 Cordón Caulle eruption, Chile, J. Geophys. Res.-Sol. Ea., 120, 2242-2261, doi:10.1002/2014JB011478, 2015a.

Bonadonna, C., Cioni, R., Pistolesi, M., Elissondo, M., and Baumann, V.: Sedimentation of long-lasting wind-affected volcanic plumes: the example of the 2011 rhyolitic Cordón Caulle eruption, Chile, B. Volcanol., 77, 3, doi:10.1007/s00445-015-0900-8, 2015 b.

Bran, D., Ayesa, J., and Lopez, C.: Áreas ecológicas de Río Negro, Laboratorio de teledetección-SIG, INTA-EEA Bariloche, available at: http://sipan.inta.gob.ar/productos/ssd/rn/ae.htm, last access: 15 July 2014, 2000.

Bran, D., Ayesa, J., and Lopez, C.: Áreas ecológicas de Neuquén, Laboratorio de teledetección-SIG, INTA-EEA Bariloche, 8 pp., available at: http://sipan.inta.gov.ar/productos/ssd/vc/neuquen/ ig/PDF/AreasEcologicas_Neuquen.pdf last access: 15 July 2014, 2002.

Buteler, M., Stadler, T., López García, G. P., Lassa, M. S., Trombotto Liaudat, D., D'Adamo, P., and Fernandez-Arhex, V.: Propiedades insecticidas de la ceniza del complejo volcánico Puyehue-Cordón Caulle y su posible impacto ambiental, Revista de la Sociedad Entomológica Argentina, 70, 3-4, 149-156, 2011.

Cioni, R., Bertagnini, A., Santacroce, R., and Andronico, D.: Explosive activity and eruption scenarios at Somma-Vesuvius (Italy): a review, J. Volcanol. Geoth. Res., 178, 331-346, doi:10.1016/j.jvolgeores.2008.04.024, 2008.

Collini, E., Osores, M. S., Folch, A., Viramonte, J. G., Villarosa, G., and Salmuni, G.: Volcanic ash forecast during the June 2011 Cordón Caulle eruption, Nat. Hazards, 66, 389-412, 2012.

Corley, J., Masciocchi, M., and Pereira, A. J.: Una "buena" del volcán!!. un verano sin chaquetas!!., INTA-EEA Bariloche Publicaciones Regionales, Revista Presencia, 59, 5-8, 2012.

Daga, R., Guevara, S. R., Poire, D. G., and Arribére, M.: Characterization of tephras dispersed by the recent eruptions of volcanoes Calbuco (1961), Chaiten (2008) and Cordon Caulle Complex (1960 and 2011), in Northern Patagonia, J. S. Am. Earth Sci., 49, 1-14, 2014.

Degruyter, W. and Bonadonna, C.: Improving on mass flow rate estimates of volcanic eruptions, Geophys. Res. Lett., 39, L1630, doi:10.1029/2012GL052566, 2012.

Diario Andino Digital Villa La Angostura: http://www. diarioandino.com.ar, last access: November 2014. 
Diario de Río Negro: http://www.rionegro.com.ar, last access: November 2014.

Diario La Angostura Digital: http://www.laangosturadigital.com.ar, last access: November 2014.

Diario La Mañana del Neuquén: http://www.lmneuquen.com.ar, last access: November 2014.

Diario La Nación: http://www.lanacion.com.ar, last access: November 2014.

Diario Página 12: http://www.pagina12.com.ar, last access: November 2014.

DNPC: Edición Especial Cenizas, Boletín Dirección Nacional de Protección Civil, Año 2, 8, available at: http://www.mininterior.gov.ar/provincias/proteccionCivil/ publicaciones/boletinsobrecenizas.pdf, last access: February 2016, 2011.

Folch, A., Mingari, L., Osores, M. S., and Collini, E.: Modeling volcanic ash resuspension - application to the 14-18 October 2011 outbreak episode in central Patagonia, Argentina, Nat. Hazards Earth Syst. Sci., 14, 119-133, doi:10.5194/nhess-14-119-2014, 2014.

Gaitán, J. J., Bran, D. B., Marciani, S., Umaña, F., Ayesa, J. A., and Raffo, F.: Monitoreo de la vegetación en áreas afectadas por cenizas volcánicas en Río Negro y Neuquén, Laboratorio de teledetección-SIG. Instituto Nacional de Tecnológico Agropecuario (INTA), Estación Experimental Bariloche, 16 pp., available at: http://inta.gob.ar/sites/default/files/ script-tmp-informe_proevo3_monitoreo_vegetacion.pdf, last access: February 2016, 2011.

Ghermandi, L. and González, S.: Observaciones tempranas de la disposición de cenizas por la erupción volcánica del Cordón Caulle y sus consecuencias sobre la vegetación de la estepa el NO de la Patagonia, Asociación Argentina de Ecología, Ecología Austral, 22, 144-149, 2012.

Giraudo, C. and Villagra, S.: Informe: La producción ganadera después de la ceniza, INTA EEA Bariloche, 4 pp., available at: http://inta.gob.ar/documentos/ la-produccion-ganadera-despues-de-la-ceniza, last access: February 2016, 2011.

Hampton, S. J., Cole, J. W., Wilson, G., Wilson, T. M., and Broom, S.: Volcanic ashfall accumulation and loading on gutters and pitched roofs from laboratory empirical experiments: Implications for risk assessment, J. Volcanol. Geoth. Res., 304, 237-252, doi:10.1016/j.jvolgeores.2015.08.012, 2015.

Hildreth, W. and Drake, R. E.: Volcan Quizapu, Chilean Andes, B. Volcanol., 54, 93-125, 1992.

Horwell, C., Le Blond, J., Michnowicz, S., and Cressey, G.: Cristobalite in a rhyolitic lava dome: evolution of ash hazard, B. Volcanol., 72, 249-253, 2010.

Huerta, G.: ?Cómo afectó la ceniza volcánica a las abejas y a la actividad apícola?, INTA-EEA Bariloche Publicaciones Regionales, Revista Presencia, 57, 26-28, 2011.

Huete, A. R., Didan, K., Miura, T., Rodriguez, E., Gao, X., and Ferreira, L.: Overview of the radiometric and biophysical performance of the MODIS vegetation indices, Remote Sens. Environ., 83, 195-213, 2002.

INIBIOMA, CONICET - Comahue: Puyehue: la recuperación total de los lagos tardará un año más, Balseiro, E. and Cussac, V., available at: http://www.conicet.gov.ar/ puyehue-la-recuperacion-total-de-los-lagos-tardara-un-ano-mas, last access: February 2016, 2012.

INTA-EEA (Estaciones Experimentales Bariloche y Valle Inferior): Estado de situación y recomendaciones para el sector ganadero de la Patagonia Norte tras la erupción del volcán Puyehue, INTA, Ministerio de Agricultura, Ganadería y Pesca, 15 pp., 2011.

INTA-EEA Chubut (Estación Experimental Chubut): Efecto del volcán Puyehue en la Provincia de Chubut, Estado de situación y recomendaciones para el sector, INTA, Ministerio de Agricultura, Ganadería y Pesca, 10 pp., available at: http://www.ambiente.gov.ar/archivos/web/MSEAySACDP/file/ EfectoCenizasChubut.pdf, last access: February 2016, 2011.

Jenkins, S. F., Spence, R. J. S., Fonseca, J. F. B. D., Solidum, R. U., Wilson, T. M.: Volcanic risk assessment: Quantifying physical vulnerability in the built environment, J. Volcanol. Geoth. Res., 276, 105-120, doi:10.1016/j.jvolgeores.2014.03.002, 2014.

Johnston, D. M., Houghton, B. F., Neall, V. E., Ronan, K. R., and Paton, D.: Impacts of the 1945 and 1995-1996 Ruapehu eruptions, New Zealand: An example of increasing societal vulnerability, Geol. Soc. Am. Bull., 112, 720-726. 2000.

Kalnay, E. C., Kanamitsu, M., Kistler, R., Collins, W., Deaven, D., Gandin, L., and Woollen, J.: The NCEP/NCAR 40-year reanalysis project, B. Am. Meteorol. Soc., 77, 437-471, 1996.

Kittl, E.: Estudio sobre los fenómenos volcánicos y material caído durante la erupción del grupo del "Descabezado" en el mes de Abril de 1932, Anales del Museo Nacional de Historia Natural, Buenos Aires, 37, 321-364, 1933.

Lara, L. E.: The 2008 eruption of the Chaitén Volcano, Chile: a preliminary report, Andean Geol., 36, 125-129, 2009.

Lara, L. E., Moreno, H., Naranjo, J. A., Matthews, S., and de Arce, C. P.: Magmatic evolution of the Puyehue-Cordón Caulle Volcanic Complex $\left(40^{\circ} \mathrm{S}\right)$, Southern Andean Volcanic Zone: from shield to unusual rhyolitic fissure volcanism, J. Volcanol. Geoth. Res., 157, 343-366, 2006.

Lavigne, F. and Thouret, J. C.: Les lahars, dépôts, occurrence et dynamique: une revue des écoulements volcano-hydrologiques, B. Soc. Geol. Fr., 171, 545-558, 2000.

Magill, C., Wilson, T., and Okada, T.: Observations of tephra fall impacts from the 2011 Shinmoedake eruption, Japan, Earth Planets Space, 65, 677-698, doi:10.5047/eps.2013.05.010, 2013.

Major, J. J. and Lara, L. E.: Overview of Chaitén Volcano, Chile, and its 2008-2009 eruption, Andean Geol., 40, 196-215, 2013.

Martin, R. S., Watt, S. F. L., Pyle, D. M., Mather, T. A., Matthews, N. E., Georg, R. B., Day, J. A., Fairhead, T., Witt, M. L. I., and Quayle, B. M.: Environmental effects of ashfall in Argentina from the 2008 Chaitén volcanic eruption, J. Volcanol. Geoth. Res., 184, 462-472, 2009.

Méndez Guerrero, F.: Caza deportiva en Parque Nacional Nahuel Huapi, 2011.

Mikkan, R.: Identificación de tefras y flujos piroclásticos holocénicos en la provincia de Mendoza como base para la elaboración de cartas de riesgo volcánico, IX Jornadas Nacionales de Geografí a Física, 19-21 April 2012, Bahía Blanca, Argentina, 69-77, 2012.

Milazzo, M. F., Ancione, G., Basco, A., Lister, D. G., Salzano, E., and Maschio, G.: Potential loading damage to industrial storage tanks due to volcanic ash fallout, Nat, Hazards, 66, 939-953, doi:10.1007/s11069-012-0518-5, 2013. 
Ministerio del Interior: Consideraciones para una estrategia para la gestión integral del riesgo de desastres en Argentina, Nota Conceptual, Informe Inédito, 37 pp., 2012.

Munich Re: Topics Geo: Natural Catastrophes 2010 - Analyses, Assessments, Positions, Munich Re, Munich, Germany, 52 pp., 2011.

Naranjo, J. A., Moreno, H., and Banks, N.: La erupción del Volcán Hudson en 1991 (46 S), Región XI, Aisén, Chile, Boletín Servicio Nacional de Geología y Minería-Chile, 44, 1-50, 1993.

Pierson, T. C., Major, J. J., Amigo, A., and Moreno, H.: Acute sedimentation response to rainfall following the explosive phase of the 2008-2009 eruption of Chaitén volcano, Chile, B. Volcanol., 75, 723, doi:10.1007/s00445-013-0723-4, 2013.

Pistolesi, M., Cioni, R., Bonadonna, C., Elissondo, M., Baumann, V., Bertagnini, A., Chiari, L., Gonzales, R., Rosi, M., and Francalanci, L.: Complex dynamics of small-moderate volcanic events: the example of the 2011 rhyolitic Cordón Caulle eruption, Chile, B. Volcanol., 77, 3, doi:10.1007/s00445-014-0898-3, 2015.

Reich, M., Zúñiga, A., Amigo, A., Vargas, G., Morata, D., Palacios, C., Parada, M. A., and Garreaud, R. D.: Formation of cristobalite nanofibers during explosive volcanic eruptions, Geology, 37, 435-438, 2009.

Robles, A. C.: Consecuencias de la erupción volcánica sobre la salud del ganado en la región patagónica, Grupo de salud animal, INTA EEA Bariloche Publicaciones Regionales, Revista Presencia, 57, 20-25, 2011.

Scasso, R. A., Corbella, H., and Tiberi, P.: Sedimentological analysis of the tephra from the 12-15 August 1991 eruption of Hudson volcano, B. Volcanol., 59, 291-306, 1994.

SERNAGEOMIN-OVDAS: Reportes de actividad Volcánica, Región Los Ríos-Los Lagos, 2010 to 2012.

Siffredi, G., López, D., Ayesa J., Bianchi, E., and Becker, G.: Informe estado de los pastizales en la transecta BarilocheOnelli (Ruta Nacional 23), INTA EEA Bariloche, 7 pp., available at: http://inta.gob.ar/sites/default/files/script-tmp-informe_ estado_de_los_pastizales_en_la_transecta_bari.pdf, last access: February 2016, 2011.

Singer, B. S., Jicha, B. R., Harper, M. A., Naranjo, J. A., Lara, L. E., and Moreno-Roa, H.: Eruptive history, geochronology, and magmatic evolution of the Puyehue-Cordón Caulle volcanic complex, Chile, Geol. Soc. Am. Bull., 120, 599-618, 2008.

Stewart, C., Johnston, D. M., Leonard, G. S., Horwell, C. J., Thordarson, T., and Cronin, S. J.: Contamination of water supplies by volcanic ashfall: a literature review and simple impact modelling, J. Volcanol. Geoth. Res., 158, 296-306, doi:10.1016/j.jvolgeores.2006.07.002, 2006.
Swanson, F. J., Jones, J. A., Crisafulli, C. M., and Lara, A.: Effects of volcanic and hydrologic processes on forest vegetation: Chaitén Volcano, Chile, Andean Geol., 40, 359-391, 2013.

Tuffen, H., James, M. R., Castro, J. M., and Schipper, C. I.: Exceptional mobility of an advancing rhyolitic obsidian flow at Cordón Caulle volcano in Chile, Nature Communications, 4, 2709, doi:10.1038/ncomms3709, 2013.

Úbeda, C., Vigliano, P., Grosfeld, J., and Puntieri, J.: Posibles efectos de la ceniza volcánica del sistema Puyehue Cordón Caulle sobre diferentes componentes del ecosistema Nordpatagónico, http://www.anbariloche.com.ar/noticias/2011/06/23/, last access: March 2012, 2011.

Wardman, J. B. , Wilson, T. M., Bodger, P. S., Cole, J. W., Johnston, D. M.: Investigating the electrical conductivity of volcanic ash and its effect on HV power systems, Phys. Chem. Earth Pts. A/B/C, 45-46, 128-145, 2012.

Wilson, T., Cole, J., Johnston, D., Cronin, S., Stewart, C., and Dantas, A.: Short- and long-term evacuation of people and livestock during a volcanic crisis: lessons from the 1991 eruption of Volcán Hudson, Chile, Journal of Applied Volcanology, 1, 11 pp., 2012.

Wilson, T., Stewart, C., Bickerton, H., Baxter, P., Outes, V., Villarosa, G., and Rovere, E.: Impacts of the June 2011 PuyehueCordón Caulle volcanic complex eruption on urban infrastructure, agriculture and public health, GNS Science, New Zealand, GNS Science Report 2012/20, 88 pp., 2013.

Wilson, T. M., Cole, J. W., Stewart, C., Johnston, D. M., and Cronin, S. J.: Assessment of Long-term Impact and Recovery of the 1991 Hudson Eruption to Agriculture and Rural Communities, Patagonia, South America, GNS Science, New Zealand, GNS Science Report 2009/66, 100 pp., 2010.

Wilson, T. M., Cole, J. W., Cronin, S., Stewart, C., and Johnston, D.: Impacts on agriculture following the 1991 eruption of Vulcan Hudson, Patagonia: lessons for recovery, Nat. Hazards, 57, 185212, doi:10.1007/s11069-010-9604-8, 2011a.

Wilson, T. M., Cole, J. W., Stewart, C., Cronin, S., and Johnston, D.: Ash storms: impacts of wind-remobilised volcanic ash on rural communities and agriculture following the 1991 Hudson eruption, southern Patagonia, Chile. B. Volcanol., 73, 223-239, doi:10.1007/s00445-010-0396-1, 2011 b. 